\title{
Japan's silver market: Creating a new industry under uncertainty
}

Cornelia Storz and Werner Pascha

Frankfurt Working Papers on East Asia

IZO | Interdisciplinary Centre of East Asian Studies No

Goethe University Frankfurt am Main March 2011 www.izo.uni-frankfurt.de 
Frankfurt Working Papers on East Asia 4/2011

Edited by

\section{IZO | Interdisziplinäres Zentrum für Ostasienstudien}

Interdisciplinary Centre for East Asian Studies

Goethe University Frankfurt am Main

ISSN number (Print) $\quad$ ISSN 1869-6872

ISSN number (Online) ISSN 2190-7080

The Frankfurt Working Papers on East Asia are intended to disseminate the research results of work in progress prior to publication and to encourage academic debate and suggestions for revisions. The contents of the papers reflect the views of the authors who are solely responsible for the facts and the accuracy of the information presented herein. The Interdisciplinary Centre for East Asian Studies assumes no liability for the contents or any use thereof. All Frankfurt Working Papers on East Asia are available online and free of charge at http://www.izo.uni-frankfurt.de/Frankfurt_Working_Papers_on_East_Asia/index.html. Printed versions are available on request.

Executive editor of the series: Thomas Feldhoff

Copyright for this issue: (C) Cornelia Storz and Werner Pascha

\section{IZO | Interdisziplinäres Zentrum für Ostasienstudien}

Interdisciplinary Centre for East Asian Studies

Goethe University Frankfurt am Main

Senckenberganlage 31

D-60325 Frankfurt am Main

T: +49(0)6979823284

F: +49(0)6979823275

E: izo@uni-frankfurt.de

H: www.izo.uni-frankfurt.de 


\title{
Japan's silver market: Creating a new industry under uncertainty
}

\begin{abstract}
It has often been asked whether today's Japan will be able to move into new and promising industries, or whether it is locked into an innovation system with an inherent inability to give birth to new industries. One argument reasons that the thick institutional complementarities among labour, innovation, and finance among its enterprises and the public sector favour industrial development in sectors of intermediate uncertainty, while it is difficult to move into areas of major uncertainty. In this paper, we present the case of the silver industry or, somewhat more prosaically, the $60+$ or even 50+ industry, for which most would agree that Japan has indeed become a lead market and lead producer on the global market. For an institutional economist, the case of the silver industry is particularly interesting, because Japan's success is based on the cooperation of existing actors, the enterprise and public sector in particular, which helped overcome the information uncertainties and asymmetries involved in the new market by relying on several established mechanisms developed well before. In that sense, Japan's silver industry presents a case of of what we propose to call successful institutional path activation with the effect of an innovative market creation, instead of the problematic lockin effects that are usually associated with the term path dependence.
\end{abstract}

\section{Cornelia Storz (University of Frankfurt)}

Faculty of Economics and Business Administration and

Interdisciplinary Centre for East Asian Studies

Goethe University Frankfurt am Main

Grüneburgplatz 1, 60323 Frankfurt am Main, Germany

Email: storz@wiwi.uni-frankfurt.de

\section{Werner Pascha (University of Duisburg-Essen)}

Mercator School of Management, Department of Managerial Economics and Institute of East Asian Studies

University of Duisburg-Essen

Lotharstr. 65, 47057 Duisburg, Germany

Email: werner.pascha@uni-duisburg-essen.de 


\section{Introduction}

It has often been asked whether today's Japan will be able to move into new and promising industries, or whether it is locked into an innovation system with an inherent inability to give birth to new industries (Anchordoguy 2000; Aoki 2000; Collinson and Wilson 2006). One argument, which has in earlier years been proposed by Aoki (e. g. 1994), reasons that the thick institutional complementarities among labour, innovation, and finance among its enterprises and the public sector favour industrial development in sectors of intermediate uncertainty like medium-high-tech industries, while it is difficult to move into areas of major uncertainty, for instance high-tech industries like biotech. Therefore it is recommended to improve its institutional quality by a policy shift towards an "entrepreneurial framework" with Silicon-Valley-like institutions in the work and industrial organisation (Goto 2000; Nezu 2004), which are said to allow for a higher productivity of entrepreneurship and a higher level of competitiveness (Audretsch, Thurik 2000; Sobel 2008; Bosma, Levie 2010; van Stel et al 2005).

In this paper, we present the case of the silver industry or, somewhat more prosaically, the $60+$ or even 50+ industry, for which most would agree that Japan has indeed become a lead market and lead producer on the global market. For an institutional economist, the case of the silver industry is particularly interesting, because Japan's success is based on the cooperation of existing actors, the enterprise and public sector in particular, which helped overcome the information uncertainties and asymmetries involved in the new market by relying on several established mechanisms developed well before. In that sense, Japan's silver industry presents a case of of what we propose to call successful institutional path activation with the effect of an innovative market creation, instead of the problematic lock-in effects that are usually associated with the term path dependence (David 1997, compare Storz 2008). To understand this positive role of path activation, we will draw on economic, cultural-cognitive and sociopolitical factors to understand the unfolding dynamics as suggested by Companys and McMullen (2006).

New industries require the creation of new knowledge and new markets (Malerba 2007). This paper focuses on the latter part, on new markets, being aware that both spheres are interlinked. Empirical research on market creation is sparse and tends to focus only on selected aspects of market creation: In economics, marketing research is most developed (Buenstorf 2007; Moschis 1992; Tollin, Caru 2008), more recently, opportunity research became a new field of research (Shane 2000; Smith et al 2005); in the social sciences and political economy, the role of power, issue framing and networks is increasingly considered (Aldrich, Fiol 1994; Beckert 2007; Beckert et al 2007; Teubal et al 1991), and at the interface of neuroeconomics, psychology and evolutionary economies, the role of cognitive schemes and cultural values and their impact on market creation is explored (Sarasvathy, Dew 2005). In this paper, we start with Companys and McMullen (2007) from the assumption that the source of competitive 
advantages under fundamental uncertainty lies in the integration of objective and subjective opportunities that derive from economic, cultural-cognitive and sociopolitical factors. This approach accepts a fundamental premise in economics, namely that economic data such as demand and prices influence market creation (Fontana and Guerzoni 2007). It also agrees that information uncertainties may become a barrier towards market creation. Yet, unlike the orthodox economic approach, it posits that market creation is also fundamentally influenced by cultural-cognitive and sociopolitical factors.

The important role of the silver market for a high-income, mature, populous and ageing economy like Japan has often been recognized (Gassmann, Keupp 2005, UDe.V./TMU 2008; Kawagoe 2009; Kohlbacher, Herstatt 2008; Naikakufu 2009). Hence, what is "uncertain" about it? Uncertainty results from the fact that even if a potential demand is high, it is far less clear what this implies for specific, possibly novel products of individual firms. While consumption expenses of those 60+ since the mid 1980s have indeed significantly more increased than of those aged 35 to 39 and while the elderly in Japan are famous - also on an international scale - for their accumulated financial and real estate holdings, it is expected that also old age poverty will be a major issue in forthcoming years (Kohlbacher/Herstatt 2008). Apart, it is an open question whether the older population can be motivated to buy enough silver products at prices that recover the necessary development costs, or whether an entry into a market for elderly consumers is only possible with high opportunity costs due to a lost reputation for younger customers. Other open questions are, for instance, which products will be sought after by consumers (need does not necessarily equal market demand, as a consultant recently put it; Lippert 2008) or whether household robots will ever be successful etc. Despite the hype about the silver market, it is far from self-evident that engaging in the silver market can turn into a profitable business. A decision in favour of the production of silver products is therefore a courageous strategic decision and deserves closer scrutiny.

The following analysis of the emergence of Japan's silver market is based on publications of government agencies and of trade associations, published membership information of formal and semi-formal government agencies (which are normally published in the beginning or at the end of these reports) and of trade associations, and very simple descriptive statistics based on website analyses of leading trade associations and leading firms in the silver market: For the analysis of associations that are active in the silver market, we mainly used a recent survey of JISC (Japan Industrial Standards Committee) on the needs for standardization for elderly and disabled persons. In this survey, JISC (2003) identified 227 associations for which the emergence of the silver market is of special relevance. 134 associations answered. The demarcation of elderly and disabled persons is somewhat blurred, but we could eliminate those associations which are directly related to disabled persons (16). According to these data, there are a total of 118 trade associations (gyôkai dantai) including 13 research institutes and research associations, 25 consumer associations and 18 associations, whose target group are 
solely, or at least include, older consumers in the silver market. $41.5 \%$ of these 118 associations (49 associations) have noted silver market activities on their website. Our website analysis relies mainly on these 118 resp. 49 trade associations.

The remainder of the paper is organized as follows: After explaining why the silver market is a new market and a introduction of some general data on it (section 2), we discuss the economic, cultural-cognitive and sociopolitical factors that affected the emergence of the market in sections 3 to 5 . The paper ends with a conclusion (section 6).

\section{The new Silver Market and Japan as an early mover}

The silver market is a distinctly new market: "New" in our understanding includes "every novel element of an activity" (Plummer et al 2007: 366), so that we classify also those markets as new which may not be new objectively (Hausschildt 1993). More specifically, products and the target group are new: As for products, new products in the silver market include smaller changes as well as distinctively novel changes (Becker et al 2006; Christensen 1997). As related to the target group, there was a prior "gerontological" market that aimed at handicapped or somewhat disabled elder persons, but the present silver market targets especially at "active and healthy" consumers. The Japanese silver market should thus be considered as a new market. Having said this, we are aware that Japan's silver market may also be conveiced as a transformation of the former gerontology market into a new market with a subsegment of gerontological products, but we would argue that the property of transformation is not distinctive for Japan's silver market, but for market creation in general (Engels 2005; Sarasvathy, Dew 2005).

Further, the creation of a market is, in our understanding, an innovative act. Schumpeter (1934) has identified new products, new production methods, new forms of organizations, new sources of supply and new markets as different types of innovation. In all cases, considerable uncertainty exists since even "minor" changes are subjectively new.

Japan is widely reputed to be a frontrunner in the silver market; other leading OECD countries are seen as second-movers (DB Research 2002; DIHKJ 2010; Gassmann, Keupp 2005, UDe.V./TMU 2008: 73). As may be typical of a newly emerging market, the silver market cannot easily be demarcated. It refers to the consumption of goods and services by elderly people, sometimes referred to as the 50+ generation, sometimes only encompassing those of $65+$. It does not refer to total consumption, as some goods and services will be equal for all generations. The silver market is about those goods and services that take particular note of the needs and interests of the older generation. Besides specialized products, silver products and services are also related to universal design (UD) ${ }^{1}$ and barrier-free products and services. UD refers to broad-spectrum

\footnotetext{
${ }^{1}$ Other terms are "design for all", "inclusive design", or "accessibility".
} 
solutions that are also accessible to those with special needs, like old, frail or handicapped people, but whose added value is not limited to such special interest groups; barrier-free refers to modifications especially for those who are handicapped or disabled. As all three markets are closely linked, we will refer to aspects of all of them in this paper, to the extent that they are relevant for the silver market proper.

Table 1: Relevant trade associations, matched with major industries

Industrial sector (one digit level)

Number of

Percentage trade asso-

ciations

Ores and minerals; electricity, gas and water

2
1.7

Food products, beverages and tobacco; textiles, apparel and leather products

Other transportable goods, except metal products, 32

machinery and equipment

Metal products, machinery and equipment 36 30.5

Construction work and constructions; land 5

Trade services; hotel and restaurant services

Transport, storage and communications services

Business services; agricultural, mining and manufacturing 8 services

Total

Source: Chart compiled by authors, classification according to http://unstats.un.org/ unsd/ cr/registry/regcst.asp?Cl=9\&Lg=1, based on JISC Survey (2003), compare appendix 2 .

Due to the lack of a clear cut definition, which is indeed quite typical for the uncertainties involved in new markets, it is thus difficult to give exact numbers, or even to draw international comparisons. We therefore rely on the estimation of experts and their evaluation that Japan is a leading market (Gassmann, Keupp 2005, UDe.V./TMU 2008), taking its leading position and early market creation as given. The market volume is estimated to expand from 39 billion Yen in 2000 (approx. 39 million US\$) to 112-155 billion Yen (approx. 111-154 million US\$) in 2025 (including care and welfare; SKS 
2000, compare also DIHKJ 2010; Kawagoe 2009). The market growth rate for the silver market is estimated to be 4-5\% p. a. between $2000-2025$ (including care and welfare; SKS 2000; compare also METI 2004). Sectors with the the most promising growth perspectives are leisure, food and education (SKS 2000).

Our classification by industry of the most active trade associations moreover indicates that especially associations in those sectors with relative comparative advantages such as electrical machinery, purpose machinery, automobiles and engines (in the industrial sector of "metal products, machinery and equipment") or photochemicals (in the sector "Other transportable goods, except metal products, machinery and equipment") are active in the silver market (table 1; for an overview of Japan's comparative advantages in patent and export specialisation compare Storz and Schäfer 2010.). Most leading firms - such as Toyota, Mitsui, Sony, Matsushita, Hitachi - that are active in the silver market belong to these sectors and entered via diversification. This is a remarkably different approach from the typical U.S. model of creating new industries by means of small start ups (Rao and Singh 2001; Storz et al. 2010).

As is well known, the ageing and even decline of the population is of particular concern for Japan. Both the high life-expectancy and the low fertility contribute to the graying of Japan. While other countries experience aging-related issues as well, at least among the mature developed economies Japan is set to experience the most dramatic change (compare for data and their evaluation Kono 2008; Jones Finer 2000). It may thus seem at first sight that it is natural for Japan to have recognized the silver market and developed its potential early. However, the developments are more complex: Up to 1995, Japan was still quite a "young country", in which the aged dependency ratio was low. According to the United Nations (2000), the percentage of people over age 65 of total population in Japan was only $10.3 \%$ in 1985 (compared to the UK with $15.1 \%$ or Germany with $14.5 \%$ ) and in 1995 only $14.6 \%$ (compared to the UK with $15.9 \%$ or Germany with $15.0 \%$ ). Only in 2000, Japan became more over-aged than other OECD countries (Japan: $17.1 \%$ vs. Germany: $16.4 \%$ and UK: $16.0 \%$ ). We thus find a more or at least comparable point of departure in the middle of the ' $90 \mathrm{~s}$, but nevertheless, it was Japan that became a frontrunner in the silver market. In the following we try to understand why and how this took place. In our argumentation we will follow Companys and McMullen (2007), who distinguish economic, cultural-cognitive, and sociopolitical factors that affect market creation. We introduce the respective approaches and apply them to Japan's silver market. 


\section{The Role of Economic Factors in Creating Japan’s Silver Market}

Simplifying the matter, markets are, in a conventional economic perspective, understood as a mechanism of price formation. Market creation is thus not seen as a "problem", since it is assumed that markets will emerge in every situation in which entrepreneurs face an incentive to acquire temporary monopoly rents. In his seminal article, Arrow (1974) formulated concisely that ,when a market could be created it would be“. Going a step further, Arrow argues that the de facto given entrepreneurial opportunities result also from differences in the distribution of information, so that they are dependent on the degree of information asymmetries (Arrow 1962). In this understanding, "new data about material resources is the source of entrepreneurial opportunity" (Companys and McMullen 2007: 305) and the relative competitive advantage of a firm in creating a market results out of the discovery and exploitation of the relevant information stock. This information stock includes quite heterogeneous information, such as the expected volume of the market, the quality of demand, the need and existence of technical competences, information about consumers' willingness to pay, and also about the required institutional set-up. Institutions and organizations that reduce information asymmetries may thus contribute to market creation, since search costs are lowered. While we will enlarge this approach by cultural-cognitive and sociopolitical factors later, we nevertheless start from the economic assumption that the reduction of uncertainty by the availability of information is critical for the emergence of a new market. $^{2}$

\footnotetext{
${ }^{2}$ In this paper, we do not deal with the impact of more conventional economic factors like technological resources. A few remarks may be adequate, however. Large, established enterprises that are so prominent in the emerging Japanese silver market already bring considerable technological resources to the new field. Following the "related varieties approach" and Porter's "diamond" argument, firms strategically select those sectoral fields, in which the specific national setting and their core competences show a certain matching (Casper 2003; Casper/Whitely 2002; Casper/Lehrer/ Soskice 1999; Porter et al. 2000). If one follows Dethlefs and Martin 2006 in differentiating between three paths inside the silver market that may be chosen - (a) conventional, standard aged car techniques, (b) robotics, and (c) barrier-free technology, involving incremental improvements to existing technologies -, it is quite clear that Japanese companies do not possess considerable competitive advantages with respect to the first option due to the well-known weaknesses in the service industry. As for robotics, Japan is blessed by favourable factor input conditions, like the availability of engineers with an accumulated know-how in electronics and machinery, it profits from a high intensity of local competition - there already were some 300 producers of robotics equipment by 1987 and some of them use robots themselves -; moreover, there are favourable local demand conditions, including open-minded customers favouring novelty and demanding industrial clients; finally, this all leads to and is combined with a dense network of (potential) subcontractors and linked industries (Porter et al. 2000). With respect to the third technological path, non-cutting edge modifications towards barrier-free technologies, this is well in line with the competencies of large segments of Japan's manufacturing industries in continuous improvement and total quality control. Such competitive advantages are hard to imitate, as they depend on tacit resources like employee empowerment and executive commitment (Powell 1995), and thus give Japan a considerable competitive edge. To give but one example, Panasonic has developed a packing for hearing aid batteries in which a small slip of plastic foil is attached to the tiny batteries; this makes it much easier for elderly (or handicapped) people to insert the batteries into their hearing aid (Ude.V./TUM 2008: 65).
} 
While the literature has ascribed Japan richness in institutions that encourage learning, we will focus here on two types of organizations that contributed to the supply of information and thus reduced entrepreneurial uncertainty: councils and trade associations. Councils (shingikai) are semi-official institutions that are affiliated to ministries; in the case of the silver market, the councils are mostly related to the METI. The Industrial Structure Council is one of its most influential councils in METI. Related to the silver market, some existing subsections (bukai) of the Council have enlarged their competences to the new sector. Two active subsections are the "Section for New Growth Industries" (Shin Seichô Seisaku Bukai) and the "General Section" (Sôgô Bukai); in some cases these subsections have additional sub-working groups, so-called iinkai (e.g. 21seiki Keizai Sangyô Seisaku Kentô Shôiinkai). Since existing structures are enlarged to new functions, it is not so much the case that committees for the silver market have been newly established, but that existing committees have taken up this subject. This approach can also be found in other organizational units such as the JISC (Japan Industrial Standards Committee; JISC 2003) ${ }^{3}$. This pattern is one reason why we speak of path activitation: the existing institutions are reinforced and enlarged in their function to new objects. The councils fulfill an important internal function in ministries in order to identify and prepare information that is critical to policy making, but they also distribute the collected information to private sector and the general public (e.g. by publishing the reports on their website).

Trade associations are a further key institution for the supply of new data. Depending inter alia on their legal form, they are more or less close to the ministries. Since the silver market is a trans-sectoral market, the exact number of associations that are related to it is difficult to identify. In this paper, the survey of JISC (Japan Industrial Standards Committee) on the needs for standardization for elderly and disabled persons is used (compare introduction for details, JISC 2003). Our simple descriptive statistics show for the 118 trade associations active in the silver market that they have been founded on average 44 years ago, and that they are highly focused in their membership (e.g. The Japan Federation of Medical Devices Associations, The Japan Small Cutting Tools' Association or Japan Automatic Identification Systems Association). On average, those trade associations that noted silver market activities on their website (49 associations) mention on average 2.2 activities (out of an average 5.5 categories on their websites); most activities are related to "news", to "products", "publications" and "survey/research". We are aware that these activities can be only taken as a very rough indicator of an association's activities, as they do not give any qualitative weight to these activities, but they may help to understand that there is a considerable relevance of new market activities for these associations. Measured in terms of activities mentioned on the website, the most active organizations are the "Tokyo Metropolitan Industrial Technology Research Center” (Tôkyô Toritsu Sangyô Gijutsu Kenkyû Sentâ), the "Illuminating Engineering Institute of Japan" (Shadan Hôjin Shômei Gakkai), the

\footnotetext{
${ }^{3}$ This does not exclude that new councils are formed (e.g. Kôreisha Shôgaisha Hairyô Seikatsuyôhin no Hyôjunka ni kansuru Chôsa Kenkyû Iinkai at JISC in 2001; JISC 2003).
} 
"New Office Promotion Association" (Shadan Hôjin Nyû Ofisu Suishin Kyôgikai), the "Fire Equipment and Safety Center of Japan" (Zaidan Hôjin Nihon Shôbô Setsubi Anzen Sentâ), the "Japan Federation of Printing Industries (JFPI)" (Shadan Hôjin Nihon Insatsu Sangyô Rengôkai) and the "Kitchen and Bath Association" (Kicchin - Basu Kôgyôkai) ${ }^{4}$ (Appendix 1).

Table 2: Comparison between perceptions of barriers to introduce universal design in facilities of Japanese and UK companies

Barriers

Survey in Japan

Survey in the UK

Manufactures Retailers

Technical complexity

$39.1 \%$

$26 \%$

$60 \%$

Lack of business case

$39.1 \%$

$57 \%$

$53 \%$

Unable to achieve

$39.1 \%$

$30 \%$

$40 \%$

Lack of knowledge, technique

$36.8 \%$

$39 \%$

$40 \%$

and methods

Lack of resources or guidance

$34.5 \%$

$48 \%$

$53 \%$

Source: Dong et al. (2004), Data Appendix

Reports and studies of councils as well as trade associations contain detailed market forecasts, for instance, like predictions for different subsectors, information on the quality of demand, the relevant technological fields, information about consumers' willingness to pay as well as case studies of successful product and service developments (METI 2004). The scope and depth of the information is remarkable. Further, it seems that in an international comparison, Japan has picked up the issues of ageing much earlier and more forcefully than other, also ageing countries. For instance, yearly White Books on the ageing society have been published by the Japanese government since 1996 (see the overview at http://www8.cao.go.jp/kourei/whitepaper/index-w.html), while the German government has commissioned and published only one major report in $2007^{5}$. A comparative survey in a subsegment of the silver market - the facility market - illustrates that information, here summarized as "lack of business case", "lack of knowledge" and "lack of guidance", appears to be less a problem for Japanese firms than for firms in the U.K. (table 2).

\footnotetext{
${ }^{4}$ Except in the latter case, the English names are the official translations.

${ }^{5}$ Also private research is scarce. Exceptions are Deutsche Bank Research 2007, DIHKJ 2010.
} 
Even if we have to be cautious to draw final conclusions and though more thorough analysis is needed, the availability of new data seems to have contributed to a reduction of entrepreneurial uncertainty. If this is indeed the case, established mechanisms of economic policy making, that is the inclusion of councils and trade associations, were one key factor for the emergence of the industry.

\section{The Role of Cultural-Cognitive Factors in Creating Japan's Silver Market}

While the economic approach starts from the assumption that new data about material resources is relevant, the world is full of examples of organisations that were unable to transform themselves despite the best information of the management (Tushman and Anderson, 1997; Tushman and O'Reilly 1997). Even if information is provided, firms do not necessarily take notice of the new information, so that relevant information is often not translated into the decision to explore new markets. As Powell (1998: 236) framed it, "attention is the scarcest commodity in organizations". The emergence of advanced information and communication technologies does not necessarily solve this problem, since they increase the total volume of information, possibly inducing even a "cognitive overload" (Kasper/Streit 998: 118).

Why is attention scarce, and why is it so difficult to re-direct attention from existing exploiting strategies to the exploration of new markets? One dominant explanation refers to cultural-cognitive factors: It is not only the availability of data that is decisive, but the subjective interpretation of data which follows the respective internal order of the mind. Thus, by different perceptions of the external world, two decision tasks may lead to different results. Search and selection processes take place within these domains - "context matters", as Smith (2003: 486) has put it. Different contexts define differently "what is feasible, what is appropriate" (Nelson 2008: 7). In contexts encouraging exploration, firms will be more ready to start new projects than in contexts where this is not the case. In short, "this perspective attributes competitive advantage to discovering and exploiting new interpretations of existing data" (Companys, Mc Mullen 2006: 306). Companys and McMullen (2006) therefore differentiate between cultural beliefs and cognitive abilities, which make actors more or less receptive towards opportunities and the creation of new markets.

Cultural factors relate to social norms, attitudes and beliefs, and since they are path dependent, actors will be relatively stable in their cultural dispositions and in their cultural knowledge, and thus perceive and enact given opportunities in relatively stable ways. Certain social norms may thus trigger the exploration of new opportunities or, vice versa, induce an inherent inability to change the path dependent information processing of human beings and lead to lock in effects in established patterns of perception (Cho and Hambrick 2006; Müller-Stewens and Lechner 205). 
Cognitive factors relate to learning and to changes in human capital. In market creation, it is decisive how cognition is coined in a way that information - here: the ageing of a population - can enter the firm easily and trigger an "attentional change" (Cho and Hambrick 2006). Research has identified mainly two conditions that help to unlock of established cognitive paths: centrality and credibility. Centrality refers to the fact that the delivered information should be relevant for the accomplishment of the firms' tasks, that the quality of information should be high and that it should be easy to implement. Credibility relates to the confidence in the source of information; high confidence may be e.g. achieved through long-established networks (Deshpande, Zaltman 1982; Picot, Scheuble 1997, Soble 2008) ${ }^{6}$. Put differently, information that is perceived as being credible and as being central for firms' activities will more easily become part of the firm's knowledge stock.

Starting with cultural beliefs, it may be expected that certain mentalities usually associated with Japan influenced the early market creation significantly (Peng and Akutsu 2001), namely beliefs (a) with respect to age and (b) with respect to uncertainty.

At first glance, it seems plausible that a positive belief towards age affects market creation positively: The inclination of revering old people and showing filial piety, based on Confucian traditions, almost seems proverbial. Moreover, the relatively high share of elder parents living together with their children is an often-repeated stylized fact. In arts and handicraft, there is an established tradition of outstanding elder teachers (sensei), which also may evoke the impression of a culture that has a positive connotation of age (Formanek 2008). It fits into this picture that in TV advertising, recent content analysis identified a positive attitude towards ageing (Prieler et al 2009). In business life, the high share of older entrepreneurs may be an indicator of a certain reputation of active elder people. Finally, perhaps the most prominent case in business life is the still prevalent seniority principle, which is expressed in renumeration and career paths positively associated with age, and which is also expressed in the advanced age of most Japanese board directors. All these factors may help to create a positive environment for the development of silver products. However, a behaviour of taking care of one's parents can also be "strategic": the child looks after the parent in order to eventually enjoy the fruits of a sizeable bequest that is still cunningly held back by the senior (Tachibanaki 1994); an argument which is of special relevance due to Japan's weakly developed welfare system. There is also empirical evidence in Japanese literature, folklore and current media that the views on old age are more ambivalent than one might expect on the first glance (Formanek 2008, Gebhardt 2008), and according to international surveys, Japanese agreed more often than Westerners with a stereotype that elderly people are "grouchy" or "selfish" (Koyano 1997: 215-217).

\footnotetext{
${ }^{6}$ Needless to say and exemplified by the reference to marketing research, also economics realized the problem of knowledge generation and knowledge utilization. Alvarez and Barney (2007) e.g. stress that there is not a simple "reduction" of information asymmetries but that the transformation of information into a knowledge stocks is more equivalent to Bayesian updating. For analytical clearness and following the differentiation of Companys and McMullen (2006) we suggest nevertheless a differentiation between the economic and the cultural-cognitive school.
} 
Further, beliefs towards uncertainty could be another background factor, independent from the peculiar environment of ageing and silver industry, but still decisive for the willingness of firms to accept risks or uncertainties when opening a new market ${ }^{7}$. Again, evidence as well as interpretation are not simple: Taking Hofstede's scheme as the most frequently used, if not uncontroversial approach, uncertainty avoidance can be conceived to lead towards a reduced inclination to treat virgin ground. Pulications in the context of the Global Entrepreneurship Monitor (Bosma, Levie 2010; Sobel 2008) and popular media (New York Times 2005) argue that a higher risk friendliness does indeed enhance entrepreneurship. However, and somewhat surprising, comparative empirical research has shown that "uncertainty avoidance values appear to induce greater openness toward change" (Geletkanycz 1997: 627) and this puzzling surprise has also been noted for Japan in particular (Schneider/DeMeyer1991: 316). The reason could be that actors from an uncertainty-tolerant culture are more patient when following an earlier chosen strategy. Together with the social norm of long-term orientation where Japan scores high in the Hofstede framework, beliefs towards uncertainty may strengthen the openness of Japanese senior managers towards change (Geletkanycz 1997).

Apart from cultural traits, cognitive factors related to "conscious intellectual activities" (Merriam-Webster) could be important as well, since the "value of material objects depends on how they are used" (Companys, Mc Mullen 2006: 306). They affect the readiness to absorb new information and to mould existing perceptions of the world. In our section on economic factors, we introduced two organizations that supply new data, namely councils and trade associations. The two properties of centrality and credibility are central for inducing an "attentional change" (Picot, Scheuble 1997, Soble 2008). Both organizations offer data that are central and credible from the firms' point of view.

- Centrality: Councils publish regularly and with a rich set of data, and the presentation of data is needs-oriented as, e.g., many case studies are included. The quality of information may be explained inter alia by the composition of the councils; we will see in the section on sociopolitical factors that the private sector is itself a member. The comprehensive use of explorative case studies may help firms in understanding the relevance of the information. The same holds true for trade associations: In the case of trade associations, the focus of membership on the three or four digit level of industrial classification eases the handling of highly specified information. The long standing membership in many associations makes it easier for the associations to deliver central information.

- Credibility: The activities of the councils as well as of the trade associations related to the silver market mainly evolved as branches of existing activities and/or organizations, which supports a continuity of networks. The long

\footnotetext{
${ }^{7}$ For simplification, we equalize uncertainty and risk in this context.
} 
duration of such networks also facilitates the transfer of sticky knowledge, and the experience in information dissemination should enhance efficiency. Entrepreneurial uncertainty in the silver market is thus significantly reduced, and the expectation formation process considerably influenced.

On the level of instruments to support such cognitive processes, Japanese firms are known for a tradition and emphasis to influence their staff through slogans or keywords that communicate certain messages (Feldmann 2007; Pascha/Haaf 1994); such mechanisms of developing and utilizing slogans can also be traced on the wider level of interfirm networks and with respect to the firm-state nexus in specific arenas (Harada/ Pascha 1987). An alert cognitive framing allows firms an ex ante common understanding of future innovation paths, which contributes to an easier search process for innovations (Takeuchi and Nonaka eds. 2004). Examples in the "silver" automobile industry include Toyota's concept of the "Raum" car as a new concept of lifestyle (also able to carry a surfboard or other bulky stuff; Moerke/Kamann 2005), the "Porte" of Toyota's fleet (Macdonald 2006) or, also of Toyota and already in the 1960s, the Welcab (from "welfare" and "cabin"), Honda is engaged in "welfare vehicles", Nissan promotes a "life care vehicle qualified shop system" and Mitsubishi Motors follows a concept named "Hearty Run", to name but a few examples (Moerke 2008). Further evidence is necessary, but it seems that these phrases encompass more than just "product names", namely new concepts of lifestyle, thus working as an important cognitive framing mechanism within enterprises, between enterprises and in terms of communicating with potential customers.

While this short overview was necessarily superficial in nature and more empirical research is needed to substantiate our considerations, there is a certain plausibility that cultural-cognitive factors positively affected the industry's emergence - less in the frequently and oversimplistic expected way of distinct cultural norms towards ageing, but rather by norms that affect the general attitude towards innovative projects and by an institutional configuration that stimulates learning processes via established supplier of soft information ${ }^{8}$.

\section{The Role of Sociopolitical Factors in Creating Japan's Silver Market}

The sociopolitical school refers to governance mechanisms and the institutional set-up imposed by regulatory entities, which create incentives for firms (and to which much of the literature on "entrepreneurial economy" refers to) and asks how such institutional configurations come into being (Companys and McMullen 2006). As for governance

\footnotetext{
${ }^{8}$ This appraisal is also in line with recent empirical economics (compare for an overview Storz, Schäfer 2010). Having said this, we are not yet able to understand the mechanisms why councils and trade associations themselves have been ready for an early "attentional shift".
} 
mechanisms, also Porter et al. (2000) in their seminal analysis on the competitiveness of nations have argued that an early formulation of demanding national quality, safety and other requirements may enhance the sophistication of local demand by pushing companies to develop higher value products. Examples include the setting of standards or the definition of product quality, but also the way how attention is shaped and information distributed. Faced with these institutions, and here the sociopolitical schools goes one step further, entrepreneurs must "mobilize and organize others to exploit these opportunities" (Companys, Mc Mullen 2006: 306-307, compare for Japan Storz 2007). Thus, especially the role (and also necessity) of bargaining power in market creation is accentuated (basically Olson and Kähkönen 2000; Hollingsworth 2002), by which economic actors seek to influence markets and governments. New markets should therefore be also understood as "a function of firm policies" (Samuels 2004). ${ }^{9}$

Starting with governance mechanisms, they are "extremely important in the discovery and exploitation of entrepreneurial opportunities" (Companys, Mc Mullen 2006: 306). Often, this is considered with reference to high-tech industries that potentially pose serious health or environmental hazards (Rao/Singh 2001). In such fields, the role of the government is almost self-evident in terms of creating - or, indeed, failing to create - important boundary conditions for a new market to emerge. However, even in a field like the silver market, for which the case for strong government intervention may be less clear, this force can be traced. An important field to demonstrate the relevance of this propostion is barrier-free products (which encompasses, as discussed above, a major intersection with silver industry). Long-term government planning and legislation developed after a Year of the Disabled in 1981, the UN launch of the Decade for the Disabled in 1983 and some surprisingly effective lobbying of civil society pressure groups (Heyer 1999). This resulted, among others measures, in a 1984 revision of the Law for the Welfare of Physically Disabled Persons, a 1994 law for easier access to public buildings and, in 2000, a "Law for Promoting Easily Accessible Public Transportation Infrastructure for the Aged and the Disabled." In a comparative study commissioned by the International Facility Management Association on the perceptions of so-called inclusive design for facility management among manufacturers and retailers around 2003, it was found that government regulation, guidelines and standards are important drivers for Japanese companies, while a notion of a "potential market" seems less important (see table 3).

Next, related to the endogenous forces altering and influencing the governance mechanisms, a large amount of literature classifies Japan as a coordinated market economy in which coordinating institutions beyond the market fulfil a critical role (Amable 2003; Crouch 2005; Hall and Soskice 2001; Hollingsworth et al 1994; Soskice 1999). While this does not necessarily mean that institutional configurations are formulated in a strategic cooperation of the public and the private sector, politico-economic research on Japan has elaborated that the private sector is deeply involved in processes of economic

\footnotetext{
${ }^{9}$ Ultimately, this can also lead to regulatory or policy capture, which creates rents for firms to appropriate, while new growth opportunities may be sacrificed.
} 
policymaking in co-creating distinct governance mechanisms, especially by councils and trade associations. While there is some discussion on the impact of bureaucrats on policymaking in the councils, a consensus has emerged that there is a political interest in including private sector's knowledge into policymaking (Aldrich, Fiol 1994; Itami 1993; Lehmbruch1995; Schaede 2000; Schwartz 1993). As for trade associations, Schaede (2000: 67) also argues that they "face a tradeoff between political influence through large size on the one hand, and effective internal self-regulation through focused membership on the other hand."

\section{Table 3: Drivers for the introduction of inclusive design in business facilities of Japanese and UK companies}

Drivers

Survey in Japan Survey in the UK

\begin{tabular}{llll} 
& & Manufacturers & Retailers \\
\hline Consumer dissatisfaction & $77.0 \%$ & $78 \%$ & $81 \%$ \\
Potential market & $44.8 \%$ & $74 \%$ & $81 \%$ \\
Guidelines and standards & $53.7 \%$ & $43 \%$ & $50 \%$ \\
Government regulations & $50.9 \%$ & $48 \%$ & $44 \%$ \\
Fundamental techniques/ & $42.9 \%$ & $48 \%$ & $56 \%$ \\
Tools and methods & & & \\
Consumer/Public awareness & $42.3 \%$ & $39 \%$ & $69 \%$
\end{tabular}

Source: Dong et al. (2004), Data Appendix

Some examples indicate that councils and trade associations in the silver market were successful in leveraging ideological frames and in using their political skills for altering governance mechanisms:

- Existing subsections (bukai) of the Industrial Structure Council, one of the most influential councils of METI, have enlarged their competences to the new silver market. As is typical for councils in general, also the members of those sections (bukai) or subsections (iinkai) that directly relate to the silver market are mainly from business, trade associations, universities, and research institutes; members of the respective ministry or agency often participate as a "guest" (kankeisha), although this may belittle their actual role. To give one example, the "Section for New Growth Industries" (Shin Seichô Seisaku Bukai), a subsection of the "General Section" (Sôgô Bukai) of the Industrial Structure Council, has 22 members, among them 9 from leading firms (President Publishers, Good Will 
Group, Recruit, Hitachi, Matsushita, Mitsui, Sony, Mitsubishi, Toyota), 1 from the media (Nihon Keizai Shinbun), 8 from mostly high-ranking universities (Tokyo University, Hitotsubashi University, etc.), 3 from associations (labour union, Japan Energy Assocation, NGO Human Service), and 1 administrative participant (SKS 2000).

- There is evidence that regular publication activities affect industrial policy making. Some examples, starting with the reports of the Industrial Structure Council (SKS 2000) and METI's strategy on the creation of new industries (METI 2004). Based on the reports of the Industrial Structure Council, METI has identified the silver market as an important growth industry. In its "Strategy for the Creation of New Industries" of 2004, METI (2004: 13-15) identified seven future industries. One growth field contains the silver market (SKS 2000), giving Japan the opportunity to position itself in certain sectors as a lead market (METI 2004). Further, the accessibility of information processing equipment, which is now a "hot topic" in international standardization, has been recognized by the Ministry in 1989, when it released the "Description of Accessibility Guidelines for Use of Computers by People with Disabilities and Elderly" (June 1990), which became the predecessor of the international ISO/IEC Guideline 71 (ISO/IEC Guide 71; Iizuka 2005). These activities have been prepared by the JISC and are partially implemented by trade associations (see below). Finally, there is also a more indirect exertion of influence, namely by research activities of trade associations in the form of contract research which allows them agenda setting (itaku chôsa; compare e.g. Kyôyôhin 2007 c).

- Trade associations play an important role in helping entrepreneurs to promote the cognitive legitimacy of an industry. There are two important new foundations of trade associations in the silver market: The Accessible Design Foundation of Japan (Kyôyôhin Foundation) of 1999 and the International Association for Universal Design of 2003. In both cases, the associations stand for the larger firms in the market. These associations represent the market to government agencies, they issue trade journals and newsletter (IAUD 2010; KSK 2010), organize workshops and exhibitions, and help formulate product and process standards. They also dispatchd representatives to the councils. For the preparation of their reports, they also install working councils. The working council of the Kyoyôhin Foundation for instance, which was in charge ofpreparing the "Final Report on Needs of Elder and Disabled People", counted 19 members, 12 from associations ( 4 of them from the Kyoyohin Foundation), 2 from firms and 3 from universities (2 else; Kyôyôhin 2007 c: 6).

- The Accessible Design Foundation of Japan continues the activities of the E\&C Project of 1991, which has focused on surveys and standardization, and was founded in 1999. Its focus is on universal design. The foundation aims at diffusing universal design products and services, and to develop specific quality requirements. Their White Book contains definitions, reports on market growth 
and markets forecasts. Definitions of the market seem to be somewhat sophisticated, but they play a central role in the perception of opportunities since they make a diffuse idea - silver market, universal design -clearer and help firms to identify where new opportunities may emerge. The results of market forecasts are diffused to the members. Moreover, seminars on the silver market are offered. Data are collected from 1995 onwards. In a forecast of 2005, e.g., arguments for the necessity of developing universal design products for selected subsectors are listed, such as elevators, vending machines, busses or cameras (KSK 2007). With the legal form of an incorporated foundation (zaidan hôjin), the association belongs to the group of "approved associations" which ministries (in this case the METI) have periodically to approve in order to obtain subsidies and tax allowances.

- The Accessible Design Foundation of Japan had the chairmanship for the above mentioned standard 71, the "Guidelines for standard developers to address the needs of older persons and persons with disabilities", which was published in 2001 (ISO/IEC Guideline 71). Here, the close networking of (private) trade associations and ministries becomes most visible: The guidelines have been developed by the METI, prepared by the councils, and the implementation into a standard is carried out by the Japan Kyôyôhin Foundation. The standard aims at informing and raising awareness "about how human abilities impact on the usability of products, services and environments" (ISO 2001) by assuring "accessibility" or, less technically, the "universal design" of products and services. The ergonomic content is new since most technical norms have focused on metrological measurement and other usage properties. Concrete applications are e.g. white goods (household appliances), machines (vending machines, ATM), printer, fax machines and ICT technologies in general; thus, they represent sectors and technologies in which Japan possesses comparative advantages. Related to accessibility, Japan holds leading positions in sub-committees of ISO (JISC 2003). In order to increase its impact in ISO further, the Accessible Design Foundation of Japan seeks cooperation with Asian standardization organizations, especially for suggesting sector-specific stan-dards building on the standard 71 (Kyôyôhin 2007a). Such policy networking may create potentials in opening up international markets, particularly through international standardsetting (DKE 2007; compare further Iizuka 2005; JISC 2003; Kyôyôhin 2007a, b), for which experts ${ }^{10}$ ascribe Japan a "certain leading role" (DKE 2007; own translation) in the enlargement of international technical standards on accessibility (compare further Iizuka 2005; JISC 2003).

\footnotetext{
10 'Experts' refer to experts in the DKE (Deutsche Kommission Elektrotechnik Elektronik Informationstechnik), that is the German commission for electrical engineering electronics, and information engineering) which is affiliated to the national German Institute for Standardization (DIN).
} 
- In 2003, leading companies (as is typical for new industries) took the initiative and broadened their activities towards a more encompassing setting, establishing the International Association for Universal Design (IAUD). Most members are large Japanese enterprises: Among its 143 regular members (as of September 2008), 77 are from the First Section of the Tokyo Stock Exchange, a further 31 are subsidiaries of First Section companies, 1 is from the Second Section and only 34 are not related - or at least could not verified to be associated to either section ${ }^{11}$. Like the Accessible Design Foundation of Japan, the IAUD is particularly interested to raise public awareness about UD, for instance by introducing the concept in schools, universities and by seeking contacts with the state. In 2006, the association has launched a major inter-national conference on UD in Kyoto. One issue of particular interest during that conference was how UD is to be promoted further, either through state activities (for instance, prescribing certain product features), or fostering the concept through "soft" measures like awards or open competitive biddings. Participants are said to have agreed that the latter approach should be taken (Ude.V./TUM 2008).

Private business activities thus helped in creating a common vocabulary and outlook, among the industry sector and beyond, and worked as vehicles for collective action. Further, they contributed to a creation of cognitive legitimacy by initiating the formulation of government guidelines and standards. Seen in perspective, the development of the silver market in Japan is progressing in a peculiar co-evolution of private business and state activities.

\section{Conclusion and Implications}

In this paper, we have looked into the creation of new markets and taken Japan's silver market as a case of market creation under considerable uncertainty. What have we learned about this new market, in which Japan seems to be on track to expand its lead position? Simply referring to the promise of the eventual size of the silver market was clearly found insufficient as an explanation for market creation because of the uncertainties that could hinder a given company to reap eventual benefits. Based on a paper of Companys and McMullen (2006), we conceive further economic as well as culturalcognitive and sociopolitical elements as key factors that affect the emergence of the new market.

Even if we have to be cautious to draw final conclusions, the availability of new data seemed to be an important source (and "economic factor") for discovering entrepreneurial opportunities in the Japanese silver market. Even if a more thorough analysis is needed, the established path of economic policy making - the inclusion of councils and trade associations - seems to be a further critical key factor for the emergence of the

\footnotetext{
${ }^{11}$ Results of website research.
} 
industry. Also cultural-cognitive factors affected the market. Even if a cultural determinism could be discarded, as cultural traditions are much more varied in Japan than stereotypes of Confucian-style respect for age or filial piety may suggest, uncertainty avoidance of Japanese managers seems not to have played a negative role, due to its embeddedness in social norms of long-term cooperation that helped to develop a positive attitude towards change. Apart, the centrality and credibility of the information supplied by councils and trade associations seems to have triggered an attentional change in that information was transferred into subjective knowledge. Finally, we looked at the effects of sociopolitical factors, in particular the governance mechanisms and conditions of their emergence. "Hard" regulation is less important for silver industry than for many other innovative industries like biotechnology with their potential hazards. Still, where regulation does play a role, like during the introduction of barrierfree technology around 1990, it did give Japanese silver products in this field a crucial push. Our illustrations indicate further that private business activities helped in creating a common vocabulary and outlook, and as vehicles for collective action, they contributed to creating cognitive legitimacy by initiating the formulation of guidelines and standards. That is why we think that markets do not only emerge, but that it is appropriate to conceive them as being created.

What can we learn beyond the case of Japan's silver industry itself? We have seen that Japanese firms do not have an inbuilt inability to create novelty as is sometimes suggested (Anchordoguy 2000; Aoki 2000; Collinson and Wilson 2006; Goto 2000; Nezu 2004). At least in cases where established enterprises can utilise their peculiar resource endowment and where one does not need to rely on Japan's (weak) venture sector, its firms can be very successful. The plasticity of available institutions on the one hand, and the ability of strategic selection of appropriate subsectors on the other hand should not be underestimated. Especially, it is noteworthy that Japanese business brings to bear a number of valuable resources to develop new markets, including informal and formal institutions. In this paper we focussed on the formal institutions of councils and trade associations. It became clear that one valuable resource Japanese firms could draw upon to overcome cognitive path dependencies is soft regulation in the sense of transforming established expectation models by information-oriented, credible policies, both involving the state and business. While it has sometimes been argued that Japanese information networks serve to exclude outsiders and foreigners, we notice a different function here: to influence the cognitive realization, thus over-come myopia and create positive externalities for all actors involved. Institutional constraints, as recently stressed in the innovation literature (compare for a short over-view Storz, Schäfer 2010) may thus, in a pointed way, be interpreted as turning into comparative advantages. Path activation, i. e. the use and reinforcement of established features of state-firm relations, inter-firm relations and firms, can thus be an important asset for overcoming information-related uncertainties and for moving into new industries with their considerable ambiguities. Instead of change-impeding lock-ins that are usually associated with path dependence, we found that such continuities can help to substantially reduce information uncertainties and thus support investment and eventually industry growth. 
We call this beneficial use of continuities path activation in order to distinguish it from the somewhat problematic connotations of path dependence.

Finally, our paper has several limitations: The most important one is that we chose a broad approach, necessarily neglected the detailed processes which led to new expectation models towards the silver market. We also did not investigate why associations or councils were more open towards information on ageing and how they were able to link this with market opportunities. More research is necessary - and promising - to study under what conditions the plasticity of engrained institutional patterns can bear the fruits of successful path activation.

\section{References}

Aldrich, H. E. and C. M. Fiol. 1994. "Fools rush in? The institutional context of industry creation", Academy of Management Review 19 (4): 645-670.

Alvarez S. A. and J. B. Barney. 2000. Toward a Creation Theory of Entrepreneurship, Working Paper, Ohio: Fisher College of Business.

Alvarez, S. A. and J. B. Barney. 2007. Discovery and creation: alternative theories of entrepreneurial action, Strategic Entrepreneurship Journal.

Anchordoguy, M. 2000. "Japan's software industry: a failure of institutions." Research Policy 29 (3), 391-408.

Amable, Bruno. 2003. The Diversity of Modern Capitalism. Oxford: Oxford University Press.

Aoki, Masahiko. 2008. “Conclusion: Whither Japan’s Governance.” In Corporate Governance in Japan: Institutional Change and Organizational Diversity, eds. Masahiko Aoki, Gregory Jackson and Hideaki Miyajima. Oxford: Oxford University Press.

Aoki , Masahiko 2000. Information, Corporate Governance, and Institutional Diversity. Competitiveness in Japan, the USA, and the Transitional Economies, Oxford University Press.

Aoki, Masahiko 1994. "The Japanese Firm as a System of Attributes." In The Japanese Firm. Sources of Competitive Strength, eds. Masahiko Aoki and Ronald Dore, 11-40. Oxford: Oxford University Press.

Aoki, Masahiko, Gregory Jackson and Hideaki Miyajima, eds. 2008. Corporate Governance in Japan: Institutional Change and Organizational Diversity. Oxford: Oxford University Press.

Arrow, Kenneth J. 1962. "Economic Welfare and the Allocation of Resources for Invention." In The Rate and Direction of Inventive Activity, ed. Richard Nelson. Princeton, NJ: Princeton University Press. 
Audretsch, D. B. and A. Roy Thurik. 2000. "Capitalism and democracy in the $21^{\text {st }}$ Century: from the managed to the entrepreneurial economy." Journal of Evolutionary Economics 10: 17-34.

Arrow, Kenneth J. 1974. "Limited Knowledge and Economic Analysis." The American Economic Review 64 (1): 1-10.

Becker, Markus C., Thorbjørn Knudsen and James G. March. 2006. "Schumpeter, Winter, and the sources of novelty." Industrial and Corporate Change 15 (2): 353-371.

Beckert, J. 2007. "Die soziale Ordnung von Märkten“. In Märkte als soziale Strukturen, eds. J. Beckert, R. Diaz-Bone and H. Ganßmann, 43-63. Campus Verlag: Frankfurt/ New York.

Beckert, J., R. Diaz-Bone and H. Ganßmann, eds. 2007. Märkte als soziale Strukturen, Campus Verlag: Frankfurt/New York.

Beise, Marian. 2004. "Lead Markets: Country-specific Drivers of the International Diffusion of Innovations." Research Policy 33 (6-7): 997-1018.

Bosma, N. and J. Levie. 2010. “Global Entrepreneurship Monitor - 2009 Global Report”, Global Entrepreneurship Research Association (GERA)

Breschi, Stefano and Franco Malerba. 1997. "Sectoral innovation systems." In Systems of innovation: Technologies, Institutions and Organisations, ed. Charles Edquist. London: Pinter.

Buenstorf, G. 2007. "Creation and Pursuit of Entrepreneurial Opportunities: An Evolutionary Economics Perspective.” Small Business Economics 28: 323-337.

Casper, Steven. 2003. "The German Internet Economy and the "Silicon Valley model".” In The Global Internet Economy, ed. Bruce Kogut. Cambridge, Massachusetts: MIT Press.

Casper, Steven and Richard Whitley. 2002. "Managing Competences in Entrepreneurial Technology Firms: A comparative institutional analysis of Germany, Sweden and the UK." (presented to the Takeda Foundation Symposium 2002).

Casper, Steven, Mark Lehrer and David Soskice. 1999. "Can High-Technology Industries prosper in Germany?" Industry and Innovation 6 (1): 5-24.

Cho, Theresa S. and Donald C. Hambrick. 2006. "Attention as the Mediator between Top Management Team Characteristics and Strategic Change: The Case of Airline Deregulation.” Organization Science 17 (July-August): 453-469.

Christensen, Clayton M. 1997. The Innovator's Dilemma. Boston, Massachusetts: Harvard Business School Press.

Collinson, S. and D. Wilson. 2006. "Inertia in Japanese Organizations: Knowledge Management Routines and Failure to Innovate.” Organization Studies 9 (27): 13591388. 
Companys, Yosem E. and Jeffrey S. McMullen. 2007. "Strategic Entrepreneurs at Work: The Nature, Discovery, and Exploitation of Entrepreneurial Opportunities." Small Business Economics 28 (4): 301-322.

Crouch, Colin. 2005. "Models of Capitalism." New Political Economy 10(4): 439-456.

David, P. A.1997. "Path dependence and the quest for historical economics: one more chorus of the ballad of QWERTY". University of Oxford Discussion Papers in Economic and Social History, No. 20.

DB Research 2002: Frankfurt Voice: Demography Special, 25. Nov. 2002

Deshpande, R. and G. Zaltman. 1982. "Factors Affecting the Use of Market Research Information: A Path Analysis.” Journal of Marketing Research, XIX Feb 1982: 14-31. Dethlefs, Noriko and Brian Martin. 2006. "Japanese technology policy for aged care." Science and Public Policy 33(1): 47-57.

Deutsche Bank Research (2007) Wie warden ältere Deutsche Geld ausgeben? (Aktuelle Themen 385, Demografie Spezial).

DIHKJ: Kohlbacher, F., P. Gudorf and C. Herstatt. 2010. "Silver Business in Japan. Implications of Demographic Change for Human Resource Management and Marketing." Silver Business in Japan: Implications of Demographic Change for Human Resource Management and Marketing. Deutsche Industrie- und Handelskammer in Japan.

DiMaggio, Paul and Walter Powell. 1991. "Introduction." In The New Institutionalism in Organizational Analysis, eds. Paul DiMaggio and Walter Powell. Chicago: University of Chicago Press.

Dong, Hua, P. John Clarkson, Saeema Ahmed and Simeon Keates. 2004. Investigating perceptions of manufacturers and retailers to inclusive design. (no year; about 2004) http://bura.brunel.ac.uk/bitstream/2438/2378/1/Copy\%20of\%20journalperceptionNo24.pdf (accessed: 28 September 2010).

Engels, A. 2005. Market Creation and Transational Rule-Making, Universität HH, CGG preprint No 2, 2005.

Edquist, Charles. 1997. Systems of Innovation: Technologies, Institutions and Organizations. London: Pinter.

Feldmann, Thomas. 2007. Kultur als Determinante der Wirtschaft? Unternehmensphilosophien in Japan. Munich: iudicium.

Fontana, Roberto and Marco Guerzoni. 2007. "Incentives and uncertainty: an empirical analysis of the impact of demand on innovation." SPRU Electronic Working Paper Series 163. http://www.sussex.ac.uk/spru/documents/sewp163.pdf (accessed: 28 September 2010).

Formanek, Susanne. 2008. "Traditional Concepts and Images of Old Age in Japan.” In The Demographic Challenge: A Handbook about Japan, eds. Florian Coulmas, Harald Conrad, Annette Schad-Seifert and Gabriele Vogt. Leiden and Boston: Brill. 
DKE 2007: Fuchs, Gerhard. 2007. Accessibility in der Normung von Hausgeräten. http://www.dke.de/de/DKE-Arbeit/MitteilungenzurNormungsarbeit/2007/Seiten/ Accessibility\%20in\%20der\%20Normung\%20von\%20Hausgeraeten.aspx (accessed: 28. September 2010).

Gassmann, Oliver and Marcus Keupp. 2005. "Wachstumsmarkt der jungen Alten: Lernen von Japan." IO New Management 7-8: 15-19. http://www.ionewmanagement. ch/de/artikelanzeige/artikelanzeige.asp?pkBerichtNr=101544 (accessed: 28 September 2010).

Gebhardt, Lisette. 2008. "Age and Ageing in Contemporary Japanese Literature." In The Demographic Challenge: A Handbook about Japan, eds. Florian Coulmas, Harald Conrad, Annette Schad-Seifert and Gabriele Vogt. Leiden and Boston: Brill.

Geletkanycz, Marta A. 1997. "The Salience of 'Culture’s Consequences': The Effects of Cultural Values on Top Executive Commitment to the Status Quo." Strategic Management Journal 18(8): 615-634.

Gordon, Bill. 1998. Lifelong Learning in Japan. http://wgordon.web.wesleyan.edu/ papers/lifelrn.pdf (accessed: 28 September 2010).

Goto, A. 2000. "Japan's National Innovation System: Current Status and Problems". Oxford Review of Economic Policy 16 (2): 103-113.

Hall, Peter A. and David Soskice. 2001. Varieties of Capitalism: The Institutional Foundations of Comparative Advantage. Oxford: Oxford University Press.

Harada, Tetsushi and Werner Pascha. 1987. "The "softnomization" of Japan - A new concept to analyse economic development." ASIEN 24 (July): 1-13.

Hauschildt, Jürgen and Sören Salomo 2007. Innovationsmanagement. (4th edition). Munich: Vahlen.

Heyer, Katharina. 1999. "Between Equality and Difference: The Politics of Disability in Japan.“ Japanstudien 11: 105-133.

Hollingsworth, Joseph R. 2002. "Some Reflections on How Institutions Influence Styles of Innovation." (Paper presented to the Swedish Collegium for Advanced Study in the Social Sciences September 2002).

Hollingsworth, J. Rogers, Philippe C. Schmitter and Wolfgang Streeck, eds. 1994. Governing Capitalist Economies: Performance and Control of Economic Sectors. New York: Oxford University Press.

IAUD (International Association for Universal Design of 2003). 2010. Homepage which contains information about activities: http://www.iaud.net/ (accessed: 20 September 2010)

Iizuka, Junichi. 2005. "Introduction to Guidelines for Older Persons and Persons with Disabilities (Japan Industrial Standard X 8341) and Fujitsu's Approach to Standardisation." Fujitsu Scientific Technical Journal 41(1): 38-46. 
ISO (International Organization for Standardisation). 2001. ISO/IEC Guide 71: 2001 (Guidelines for standards developers to address the needs of older persons and personas with disabilities). http://www.iso.org/iso/iso_catalogue/catalogue_tc/catalogue_ detail.htm?csnumber=33987 (accessed: 19 September 2010).

Itami, Hiroyuki. 1993. Beyond Capitalism: Japan's People Centered Enterprise System, (Manuscript). Tokyo

JISC (Japanese Industrial Standards Committee). 2003. Kôreisha, shôgaisha e no hairyo ni kakawaru hyôjunka no susumekata ni tsuite (teigensho) (Proposals on the standardization process for the care of elderly and disabled persons). (Presented to $\mathrm{Ni}$ hon Kôgyô Hyôjun Chôsakai / Shôhisha Seisaku Tokubetsu Iinkai, 16 June 2003). http://www.jisc.go.jp/newstopics/2003/koureisya-vision.pdf (accessed: 20 September 2010)

Jones Finer, Catherine. 2000. "Aging in Industrial Societies, East and West: A Western Comparative Perspective." In Aging in East and West. Families, States, and the Elderly, eds. Vern L. Bengston, Kyong-Dong Kim, George C. Myers and Ki-Soo Eun. New York: Springer.

Kasper, Wolfgang and Manfred E. Streit. 1998. Institutional Economics. Social Order and Public Policy. Cheltenham: Edward Elgar.

Kawagoe, Masaaki. 2009. "What Is the Economic Value of Japanese Longevity?" Japanese Economy 36(3): 28-60.

Kohlbacher, F. and C.Herstatt. 2008. "Das Silbermarkt-Phänomen.” JapanMarkt (September): 8-11.

Kohlbacher, F. and C. Herstatt. 2008. The Silver Market Phenomen, J@ pan.Inc Magazine No. 80 (Aug. 31, 2008).

Kono, Shigemi. 2008. "Demographic comparisons with other countries with the emphasis on the more developed regions." In The Demographic Challenge: A Handbook about Japan, eds. Florian Coulmas, Harald Conrad, Annette Schad-Seifert and Gabriele Vogt. Leiden and Boston: Brill.

Koyano, Wataru. 1997. "Myths and facts of aging in Japan." In Aging: Asian Concepts and Experiences. Past and Present, eds. Susanne Formanek and Sepp Linhart. Vienna: Österreichische Akademie der Wissenschaften.

KSK (Kyôyôhin Suishin Kikô) (2010) Newsletter: http://www.kyoyohin-news.org/ archives/cat_10047316.html (accessed: 20 September 2010)

KSK (Kyôyôhin Suishin Kikô) (2007a): 2005nendo Kyôyôhin shijô kibo ni kansuru chôsa hôkoku (Report on the expected market volume of universally designed products) http://www.kyoyohin.org/03_download/pdf/shijyoukibo2005.pdf (accessed: 28 September 2010). 
KSK (Kyôyôhin Suishin Kikô) (2007b): Kôreisha shôgaisha hairyô bunya no chôsa kenkyû mata ha JIS gen'an sakusei - chôsa seika hôkokusho, Feb. 2007.

http://www.kyoyohin.org/03_download/pdf/syakaineeds_19.pdf (accessed: 18 September 2010)

KSK (Kyôyôhin Suishin Kikô) (2007c) Têma 2: Kôreisha shôgaisha hairyô bunya no chôsa kenkyû. Seika Hôkokusho (Keizai Sangyôshô Itaku. Shakai Nîzu taiô gata kijun sôsei chôsa kenkyû), February 2007.

Lehmbruch, Gerhard. 1995. "Ressortautonomie und die Konstitution sektoraler Politiknetzwerke." In Die Reformfähigkeit von Industriegesellschaften: Fritz W. Scharpf, Festschrift zu seinem 60. Geburtstag, eds. Karlheinz Bentele, Bernd Reissert and Roland Schettkat. Frakfurt/ Main: Campus.

Lippert, Stefan. 2008. "Zwischen Euphorie und Ernüchterung: Produkt- und Preismanagement im Silbermarkt. "JapanMarkt (September): 14-15.

Lundvall, Bengt, Björn Johnson, Esben S. Andersen and Bent Dalum. 2002. "National systems of Production, innovation and competence building." Research policy 31: 213231.

Macdonald, Alastair S. 2006. "Universal Design in Japanese technological Industries." In Designing Accessible Technology, eds. John Clarkson, Patrick Langdon and Peter Robinson. London: Springer.

Malerba, Franco. 2007: "Innovation and the dynamics and evolution of industries: Progresses and challenges." International Journal of Industrial Organization 25: 675-699.

Malerba, Franco. 2006. "Innovation and the evolution of industries." Journal of Evolutionary Economics 16 (3): 3-23.

METI (Ministry of Economy, Trade and Industry). 2004. Shin sangyô sôzô senryaku (Strategies for the creation of new industries), May 2004. http://www.meti.go.jp/policy/ economic_industrial/press/0005221/1/040518sinsangyou_honsi.pdf (accessed: 28 September 2010).

Moerke, Andreas and Simon Kamann. 2004. "Herausforderungen des demographischen Wandels: Fallbeispiel Automobilindustrie.” DIJ Working Paper 05/04. Tokyo: Deutsches Institut für Japanstudien.

Moerke, Aandreas. 2008. "The Ageing Society and Reactions of the Automobile Industry - A Case Study." In The Demographic Challenge: A Handbook about Japan, eds. Florian Coulmas Harald Conrad, Annette Schad-Seifert and Gabriele Vogt. Leiden and Boston: Brill.

Moschis, G. P. 1992: Marketing to Older Consumers, Westport, Connecticut, London: Quorum Books.

Müller-Stewens, Günter and Christoph Lechner. 2005. Strategisches Management. Stuttgart: Schäffer-Poeschel Verlag. 
Naikakufu Seisaku Tôkatsukan 2009: Kôreika no jôkyô oyobi kôreishakai taisaku no jisshi no jôkyô ni kan suru nenji hôkoku (Kôrei shakai hakusho).

http://www8.cao.go.jp/kourei/whitepaper/index-w.html (accessed: 19 September 2010)

Nelson, Richard R. 2008. "What enables rapid economic progress: What are the needed institutions." Research Policy: 37: 1-11.

New York Times. 2005. "Most Japanese boards and executives ranks are filled with lifetime employees who win those spots more through their loyality than through their creativity", in New York Times, 7 March 2005, Shake up at Sony Puts Westerner in Leader's Role.

Nezu, R. 2004. "Why did Japanese Industry Lose Out in the Global Competition During the 1990s?" The Japanese Economy 32 (1): 45-75.

Olson, Mancur and Satu Kähkönen, eds. 2000. A Not-So-Dismal Science: A Broader View of Economies and Societies. Oxford: Oxford University Press.

Pascha, Werner and Katrin Haaf. 1994. "Slogans als Instrument der japanischen Unternehmens- und Wirtschaftspolitik." Japanstudien 6: 361-386.

Peng, Kaiping and Satoshi Akutsu. 2001. "A Mentality Theory of Knowledge Creation and Transfer: Why some Smart People Resist New Ideas and Some Don't.” In Managing Industrial Knowledge, eds. Ikujiro Nonaka and David Teece. London, Thousand Oaks, New Dehli: Sage.

Picot, Arnold and Sven Scheuble. 1997. "Die Bedeutung der Information für Innovation und Wettbewerbsfähigkeit von Unternehmen." In Informationswirtschaft und Standort Deutschland, ed. Gerhard J. Mantwill. Baden-Baden: Nomos.

Plummer, Lawrance A. J., Michael Haynie and Joy Godesiabois. 2007. "An Essay on the Origins of Entrepreneurial Opportunity." Small Business Economics 28 (4): 363379.

Porter, Michael E., Hirotaka Takeuchi and Mariko Sakakibara. 2000. Can Japan Compete? Basingstoke: Macmillan.

Porter, Michael E. 1990. The competitive advantage of nations. New York: Free Press.

Powell, Thomas C. 1995. "Total Quality Management as Competitive Advantage: A Review and Empirical Study." Strategic Management Journal. 16 (1): 15-37.

Powell, W. W. 1998. "Learning from collaboration. Knowledge and networks in the biotechnology and pharmaceutical industries." California Management Review 40(3): 228-40.

Prieler, M.; Kohlbacher, F.; Hagiwara, S.; Arima, A. 2009. “Ältere Menschen in der japanischen Fernsehwerbung: Eine umfragebasierte und inhaltsanalytische Untersuchung.“ Japanstudien 21: 197-222.

Rao, Hayagreeva and Jitendra Singh. 2001. "The Construction of New Paths: Institution-Building Activity in the Early Automobile and Biotech Industries." In Path 
Dependence and Creation, eds. Raghu Garud and Peter Karnøe. Mahwah and London: Lawrence Erlbaum.

Samuels, Warren J. 2004. "Markets and Their Social Construction." Social Research 71 (2): 357-370. http://commerce.metapress.com/content/dbne368ufnyw1tul/ ?p=13325ab6737f41f882bddd8bf0d2e417\&pi=13 (accessed: 28 September 2010).

Sarasvathy, Saras D. and Nicholas Dew. 2005. "New market creation through transformation." Journal of Evolutionary Economics 15: 533-565.

Schaede, Ulrike. 2000. Cooperative Capitalism: Self-regulation, Trade Association, and the Antimonopoly Law in Japan. Oxford: Oxford University Press.

Shane, S. A. 2000. Prior knowledge and the discovery of entrepreneurial opportunities, Organization Science 11(4): 448-469.

Schneider, Susan C. and Arnoud de Meyer. 1991. "Interpreting and Responding to Strategic Issues: The Impact of National Culture.” Strategic Management Journal 12 (4): 307-320.

Schumpeter, Joseph A. 1934. The Theory of Economic Development. Cambridge, M.A.: Harvard University Press.

Schwartz, Frank. 1993. "Of fairy cloaks and familiar talks: the Politics of Consultation.” In Political Dynamics in Contemporary Japan, eds. Gary Allinson and Yasunori Sone. Ithaca, London: Cornell University Press.

SKS (Sangyô Kôzô Shingikai) 2000. 21 seiki keizai sangyô seisaku no kadai to tenbô, kyôsôryoku aru tasanka shakai no keisiei ni mukete, saishû tôshin (Economic and industrial policies and perspectives in the 21st century. Final report) http://www.meti.go.jp/kohosys/press/0000450/0/fintousin.pdf (accessed: 20 September 2010)

Smith, B. R., C. Matthews and M. Schenkel, M. 2005. "The search for and discovery of different types of entrepreneurial opportunities: The effects of tacitness and codification."Frontiers of Entrepreneurship Research 283-293.

Smith, Vernon L. 2003. "Constructivist and Ecological Rationality in Economics." The American Economic Review 93 (3): 465-508.

Sobel, Russel S. 2008. "Testing Baumol: Institutional Quality and the Productivity of Entrepreneurship.“ Journal of Business Ventureing 23 (6) (November 2008): 641-655.

Soskice, David. 1999. "Divergent Production Regimes: Coordinated and Uncoordinated Market Economies in the 1980s an 1990s." In Continuity and Change in Contemporary Capitalism, eds. Herbert Kitschelt, Peter Lange, Gary Marks and John Stephens. Cambridge: Cambridge University Press.

Storz, C. 2003. "Globalisierung, Technik, Normen. Warum weichen japanische Unternehmen von internationalen Normen ab?" Japanstudien 15: 219-246. 
Storz, C. 2007. "Compliance with International Standards: The EDIFACT and ISO 9000 Standards in Japan.” Social Science Japan Journal 10 (2): 217-241.

Storz, C. 2008. "Dynamics in Innovation Systems: Evidence from Japan's Game Software Industry, Research Policy Reference.” Research Policy 37: 1480-1491.

Storz, C., S. Lechevalier and J. Nakamura. 2010. Industrial Dynamics - the case of Japan's service robot industry, mimeo.

Storz, C. and S. Schäfer. 2010. Institutional Diversity and Innovation. Continuing and Emerging Patterns in Japan and China (with a guest contribution of Markus Conlé and a preface of Richard Whitley), Routledge, forthcoming 2010.

Tachibanaki, Toshiaki, ed. 1994. Savings and Bequests. Ann Arbor: University of Michigan Press.

Takeuchi, Hirotaka and Ikujiro Nonaka, eds. 2004. Hitotsubashi on Knowledge Management. London: Wiley and Sons.

Teubal, M., T. Yinnon and E. Zuscovitch. 1991. "Networks and market creation", Research Policy 381-392.

Tollin, K. and A. Caru, eds.2008. Strategic Market Creation: A new perspective on marketing and innovation management. Hoboken, N.J.: John Wiley \& Sons.

Tushman, Michael L. and Charles A. O'Reilly. 1997. Winning through innovation: A Practical Guide to Leading Organizational Change and Renewal. Boston, MMA: Harvard Business School Press.

Tushman, Michael L. and Philip Anderson. 1997. Managing Strategic Innovation and Change: A Collection of Readings. New York: Oxford University Press.

UDe.V./TUM (universal design e. V./Lehrstuhl für Industrial Design der TU München). 2008. Universal Design im globalen demographischen Wandel. Hanover and Munich.

United Nations 2000. Replacement Migration. Is it a solution to Declining and Ageing Populations? http://www.un.org/esa/population/publications/migration/migration.htm (accessed: 13 October 2008).UNSD (United Nations Statistics Division). 2002. Central Product Classification System. http://unstats.un.org/unsd/statcom/doc02/cpc.pdf (accessed: 28 September 2010).

Van Stel, A., M. Carree and A. R. Thurik. 2005. The Effect of Entrepreneurial Activity on National Economic Growth, Discussion Papers on Entrepreneurship, Growth and Public Policy, Max Planck Institute for Research into Economic Systems ftp://papers.econ.mpg.de/egp/discussionpapers/2005-04.pdf (accessed: 20 September 2010). 


\section{Appendix 1}

\begin{tabular}{|c|c|c|c|c|c|c|c|c|c|c|c|c|c|c|c|c|}
\hline $\begin{array}{l}\text { Name } \\
\text { (Japanese) }\end{array}$ & $\begin{array}{l}\text { Name (Tran- } \\
\text { scription) }\end{array}$ & Name (English) & 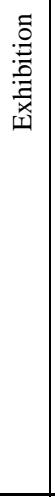 & 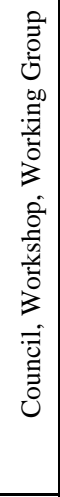 & 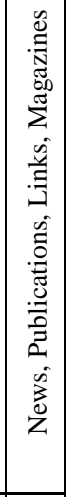 & 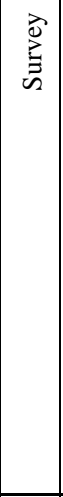 & 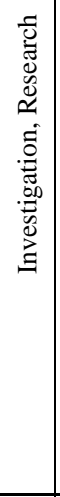 & 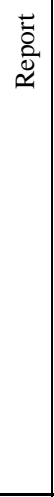 & 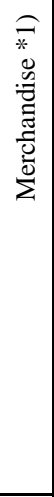 & 节 & 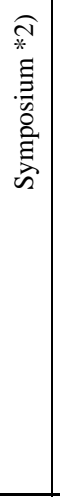 & $: \stackrel{0}{:}$ & 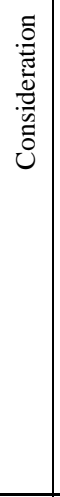 & 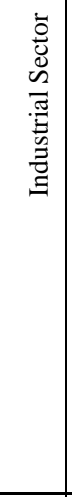 & 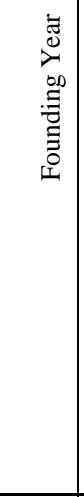 & 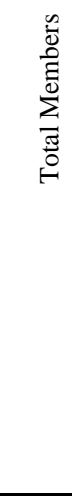 \\
\hline $\begin{array}{l}\text { IC カード } \\
\text { システム } \\
\text { 利用促進 } \\
\text { 協議会 }\end{array}$ & $\begin{array}{l}\text { IC Kâdo } \\
\text { Shisutemu Riyô } \\
\text { Sokushin } \\
\text { Kyôgikai }\end{array}$ & $\begin{array}{l}\text { Japan IC Card } \\
\text { System Applica- } \\
\text { tion Council } \\
\text { (JICSAP) }\end{array}$ & & & & & & & & & & & & 46 & 1993 & 43 \\
\hline $\begin{array}{l}\text { I SO/T } \\
\text { C } 21 \text { 事務 } \\
\text { 局 }\end{array}$ & $\begin{array}{l}\text { ISO/TC21 } \\
\text { Jimukyoku }\end{array}$ & N/A & & & & & & & & & & & & N/A & 1979 & 37 \\
\hline $\begin{array}{l}\text { 社団法人 } \\
\text { ビジネス } \\
\text { 機械・情 } \\
\text { 報システ } \\
\text { ム産業協 } \\
\text { 会 }\end{array}$ & $\begin{array}{l}\text { Shadan Hôjin } \\
\text { Bijinesu Kikai } \\
\text { - Jôhô } \\
\text { Shisutemu } \\
\text { Sangyô Kyôkai }\end{array}$ & $\begin{array}{l}\text { Japan Business } \\
\text { Machine and } \\
\text { Information } \\
\text { System Industries } \\
\text { Association } \\
\text { (JBMIA) }\end{array}$ & & $\mathrm{x}$ & & $\mathrm{x}$ & & $\mathrm{x}$ & & & & & & 46 & 1960 & 59 \\
\hline $\begin{array}{l}\text { 圧鍋連 } \\
\text { 絡協議会 }\end{array}$ & $\begin{array}{l}\text { Atsuryokunabe } \\
\text { Renraku } \\
\text { Kyôgikai }\end{array}$ & N/A & & & & & & & & & & & & 44 & N/A & N/A \\
\hline $\begin{array}{l}\text { 印刷工業 } \\
\text { 会 }\end{array}$ & $\begin{array}{l}\text { Insatsu } \\
\text { Kôgyôkai } \\
\end{array}$ & N/A & & & & & & & & & & & & 32 & 52 & 103 \\
\hline $\begin{array}{l}\text { インター } \\
\text { ホンエ業 } \\
\text { 会 }\end{array}$ & $\begin{array}{l}\text { Intâhon } \\
\text { Kôgyôkai }\end{array}$ & $\begin{array}{l}\text { Japan Interphone } \\
\text { Industry Associa- } \\
\text { tion }\end{array}$ & & $\mathrm{x}$ & & & $\mathrm{x}$ & & & & & & & 47 & 1966 & 39 \\
\hline $\begin{array}{l}\text { 社団法人 } \\
\text { 遠赤外線 } \\
\text { 協会 }\end{array}$ & $\begin{array}{l}\text { Shadan Hôjin } \\
\text { Ensekigaisen } \\
\text { Kyôkai }\end{array}$ & $\begin{array}{l}\text { Japan Far In- } \\
\text { frared Rays } \\
\text { Association } \\
\text { (JIRA) } \\
\end{array}$ & & & & & & & & & & & & 48 & 1990 & 53 \\
\hline $\begin{array}{l}\text { 鉛筆シャ } \\
\text { ープナー } \\
\text { エ業会 }\end{array}$ & $\begin{array}{l}\text { Enpitsu } \\
\text { Shâpunâ } \\
\text { Kôgyôkai }\end{array}$ & N/A & & & & & & & & & & & & 38 & N/A & N/A \\
\hline $\begin{array}{l}\text { 財団法人 } \\
\text { 家電製品 } \\
\text { 協会 }\end{array}$ & $\begin{array}{l}\text { Zaidan Hôjin } \\
\text { Kadenseihin } \\
\text { Kyôkai }\end{array}$ & $\begin{array}{l}\text { Association for } \\
\text { Electric Home } \\
\text { Appliances } \\
\text { (AEHA) } \\
\end{array}$ & & & & & & & $\mathrm{x}$ & & & $\mathrm{x}$ & & 44 & 1973 & 51 \\
\hline $\begin{array}{l}\text { 有限責任 } \\
\text { 中間法人 } \\
\text { カメラ映 } \\
\text { 像機器工 } \\
\text { 業会 }\end{array}$ & $\begin{array}{l}\text { Yûgensekinin } \\
\text { Chûkan Hôjin } \\
\text { Kamera Eizô } \\
\text { Kiki Kôgyôkai }\end{array}$ & $\begin{array}{l}\text { Camera \& Imag- } \\
\text { ing Products } \\
\text { Association } \\
\text { (CIPA) }\end{array}$ & & & & & & & & & & & & 48 & 2002 & 59 \\
\hline $\begin{array}{l}\text { キッチン } \\
\text { •バスエ } \\
\text { 業会 } \\
\end{array}$ & $\begin{array}{l}\text { Kicchin - Basu } \\
\text { Kôgyôkai }\end{array}$ & N/A & & & $\mathrm{x}$ & & $\mathrm{x}$ & & & $\mathrm{x}$ & & $\mathrm{x}$ & & 36 & 1985 & 70 \\
\hline $\begin{array}{l}\text { 社団法人 } \\
\text { 教科書協 } \\
\text { 会 }\end{array}$ & $\begin{array}{l}\text { Shadan Hôjin } \\
\text { Kyôkasho } \\
\text { Kyôkai }\end{array}$ & $\begin{array}{l}\text { Textbook Pub- } \\
\text { lishers Associa- } \\
\text { tion of Japan }\end{array}$ & & & & & & & & & & & & 32 & 1953 & 44 \\
\hline $\begin{array}{l}\text { 高圧ガス } \\
\text { 保安協会 }\end{array}$ & $\begin{array}{l}\text { Kôatsu Gasu } \\
\text { Hoan Kyôkai }\end{array}$ & $\begin{array}{l}\text { The High Pres- } \\
\text { sure Gas Safety } \\
\text { Institute of Japan } \\
\text { (KHK) }\end{array}$ & & & & & & & & & & & & 44 & 1963 & 1360 \\
\hline $\begin{array}{l}\text { 抗菌製品 } \\
\text { 技術協議 } \\
\text { 会 }\end{array}$ & $\begin{array}{l}\text { Kôkin Seihin } \\
\text { Gijutsu Kyôgi- } \\
\text { kai }\end{array}$ & $\begin{array}{l}\text { Society of In- } \\
\text { dustrial Technol- } \\
\text { ogy of } \\
\text { Antimicrobial } \\
\text { Articles } \\
\end{array}$ & & & & & & & & & & & & 35 & 1998 & 56 \\
\hline
\end{tabular}




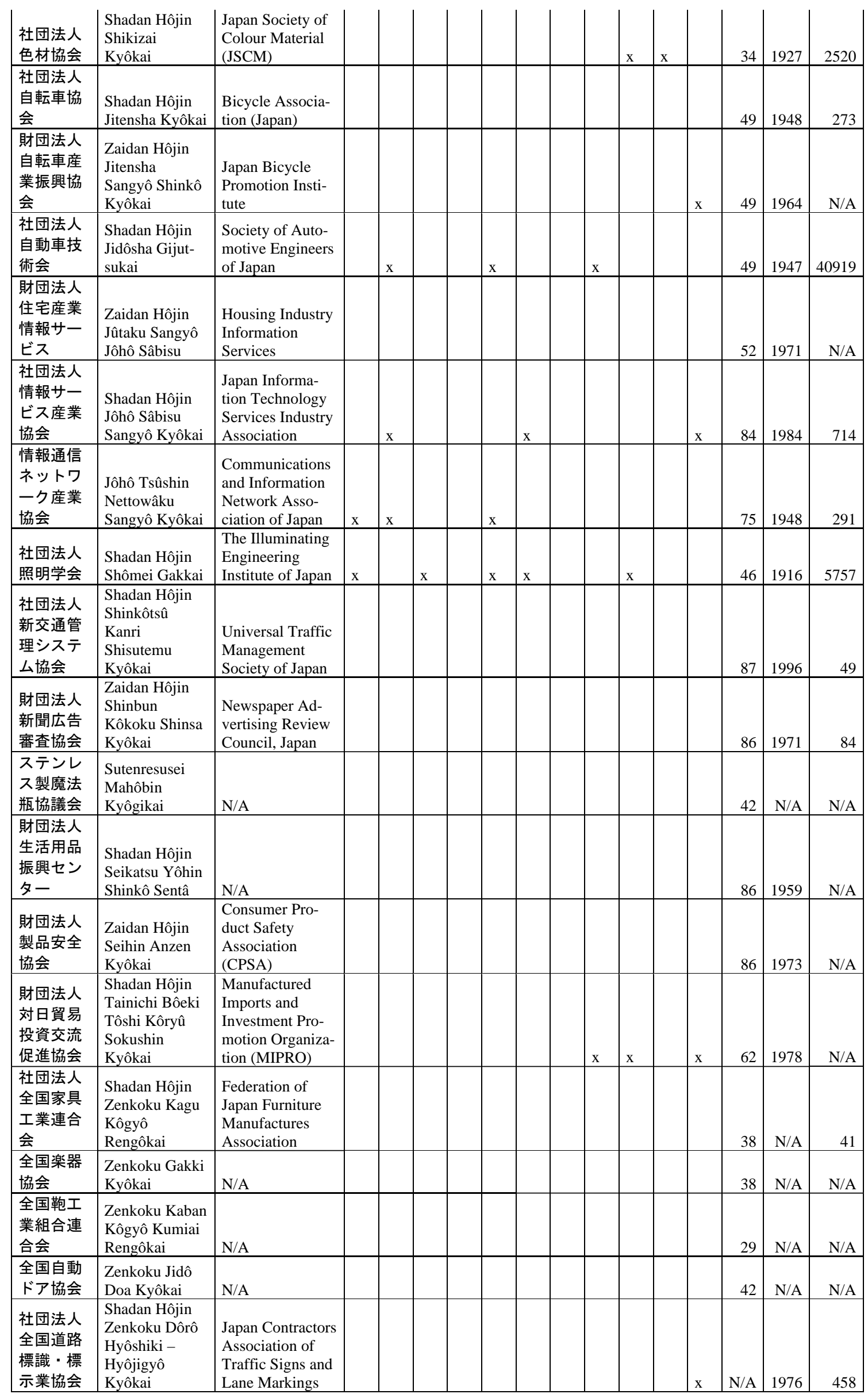




\begin{tabular}{|c|c|c|c|c|c|c|c|c|c|c|c|c|c|c|}
\hline $\begin{array}{l}\text { 全国魔法 } \\
\text { 瓶工業組 } \\
\text { 合 }\end{array}$ & $\begin{array}{l}\text { Zenkoku } \\
\text { Mahôbin } \\
\text { Kôgyô Kumiai }\end{array}$ & $\begin{array}{l}\text { All Japan } \\
\text { Vacuum Bottle } \\
\text { Association }\end{array}$ & & & & & & & & & & 42 & N/A & N/A \\
\hline $\begin{array}{l}\text { 全日本紙 } \\
\text { 製品工業 } \\
\text { 組合 }\end{array}$ & $\begin{array}{l}\text { Zen Nihon } \\
\text { Kamiseihin } \\
\text { Kôgyô Kumiai }\end{array}$ & N/A & & & & & & & & & & 32 & N/A & N/A \\
\hline $\begin{array}{l}\text { 全日本寝 } \\
\text { 具㾛装品 } \\
\text { 協会 }\end{array}$ & $\begin{array}{l}\text { Zen Nihon } \\
\text { Shingu Shin- } \\
\text { souhin Kyôkai }\end{array}$ & $\begin{array}{l}\text { All Japan Bed- } \\
\text { ding Goods } \\
\text { Association }\end{array}$ & & & & & & & & & & 38 & N/A & N/A \\
\hline $\begin{array}{l}\text { 全日本履 } \\
\text { 物団体協 } \\
\text { 議会 }\end{array}$ & $\begin{array}{l}\text { Zen Nihon } \\
\text { Hakimono } \\
\text { Dantai Kyôgi- } \\
\text { kai } \\
\end{array}$ & N/A & & & & & & & & & & 29 & N/A & N/A \\
\hline $\begin{array}{l}\text { 社団法人 } \\
\text { 電子情報 } \\
\text { 技術産業 } \\
\text { 協会 }\end{array}$ & $\begin{array}{l}\text { Shadan Hôjin } \\
\text { Denshi Jôhô } \\
\text { Gijutsu Sangyô } \\
\text { Kyôkai }\end{array}$ & $\begin{array}{l}\text { Japan Electronics } \\
\text { and Information } \\
\text { Technology } \\
\text { Industries Asso- } \\
\text { ciation (JEITA) }\end{array}$ & & & & $\mathrm{x}^{*}$ & & & & & $\mathrm{x}$ & 47 & N/A & 528 \\
\hline $\begin{array}{l}\text { トイレッ } \\
\text { トペーパ } \\
\text { ー」I S } \\
\text { 普及会 }\end{array}$ & $\begin{array}{l}\text { Toiretto Pêpâ } \\
\text { JIS Fukyûkai }\end{array}$ & N/A & & & & & & & & & & 32 & N/A & N/A \\
\hline $\begin{array}{l}\text { 東京化粧 } \\
\text { 品工業会 }\end{array}$ & $\begin{array}{l}\text { Tôkyô Ke- } \\
\text { shôhin } \\
\text { Kôgyôkai }\end{array}$ & N/A & & & & & & & & & & 35 & N/A & 405 \\
\hline $\begin{array}{l}\text { 株式会社 } \\
\text { 東京ビッ } \\
\text { グサイト }\end{array}$ & $\begin{array}{l}\text { Kabushiki } \\
\text { Gaisha Tôkyô } \\
\text { Biggu Saito }\end{array}$ & $\begin{array}{l}\text { Tokyo Big Sight } \\
\text { Inc. }\end{array}$ & & & & & & & & & & 87 & 1956 & N/A \\
\hline $\begin{array}{l}\text { 東京商工 } \\
\text { 会議所 }\end{array}$ & $\begin{array}{l}\text { Tôkyô Shôkô } \\
\text { Kai-gisho }\end{array}$ & $\begin{array}{l}\text { The Tokyo } \\
\text { Chamber of } \\
\text { Commerce and } \\
\text { Industry }\end{array}$ & $\mathrm{x}$ & & & & & & & $\mathrm{x}$ & & N/A & 1878 & 81804 \\
\hline $\begin{array}{l}\text { 東京都立 } \\
\text { 産業技術 } \\
\text { 研究セン } \\
\text { ター }\end{array}$ & $\begin{array}{l}\text { Tôkyô Toritsu } \\
\text { Sangyô Gijutsu } \\
\text { Kenkyû Sentâ }\end{array}$ & $\begin{array}{l}\text { Tokyo Metropoli- } \\
\text { tan Industrial } \\
\text { Technology } \\
\text { Research Center }\end{array}$ & $\mathrm{x}$ & $\mathrm{x}$ & $\mathrm{x}$ & & & & $\mathrm{x}$ & $\mathrm{x}$ & & N/A & 1921 & N/A \\
\hline $\begin{array}{l}\text { 日本アパ } \\
\text { レルエ業 } \\
\text { 技術研究 } \\
\text { 会 }\end{array}$ & $\begin{array}{l}\text { Nihon Apareru } \\
\text { Kôgyô Gijutsu } \\
\text { Kenkyûkai }\end{array}$ & $\begin{array}{l}\text { Japan Apparel } \\
\text { Technology and } \\
\text { Research Asso- } \\
\text { ciation (JATRA) }\end{array}$ & & & & & & & & & & 28 & 1971 & 46 \\
\hline $\begin{array}{l}\text { 社団法人 } \\
\text { 日本イベ } \\
\text { ント産業 } \\
\text { 振興協会 }\end{array}$ & $\begin{array}{l}\text { Shadan Hôjin } \\
\text { Nihon Ibento } \\
\text { Sangyô Shinkô } \\
\text { Kyôkai }\end{array}$ & $\begin{array}{l}\text { Japan Associa- } \\
\text { tion for the Pro- } \\
\text { motion of Cre- } \\
\text { ative Events } \\
\text { (JACE) }\end{array}$ & & & & $\mathrm{x}^{*}$ & & & & & & N/A & 1989 & 83 \\
\hline $\begin{array}{l}\text { 日本医療 } \\
\text { 機器産業 } \\
\text { 連合会 }\end{array}$ & $\begin{array}{l}\text { Nihon Iryôkiki } \\
\text { Sangyô } \\
\text { Rengôkai }\end{array}$ & $\begin{array}{l}\text { The Japan Feder- } \\
\text { ation of Medical } \\
\text { Devices Associa- } \\
\text { tions (JFMDA) }\end{array}$ & & & & & & & & & & 48 & 1984 & 152 \\
\hline $\begin{array}{l}\text { 日本医療 } \\
\text { 福祉設備 } \\
\text { 協会 }\end{array}$ & $\begin{array}{l}\text { Nihon Iryô } \\
\text { Fukushi Setsubi } \\
\text { Kyôkai }\end{array}$ & $\begin{array}{l}\text { Healthcare Engi- } \\
\text { neering Associa- } \\
\text { tion of Japan } \\
\text { (HEAJ) }\end{array}$ & & $\mathrm{x}$ & & & & & & & & 48 & 1953 & 800 \\
\hline $\begin{array}{l}\text { 社団法人 } \\
\text { 日本印刷 } \\
\text { 産業連合 } \\
\text { 会 }\end{array}$ & $\begin{array}{l}\text { Shadan Hôjin } \\
\text { Nihon Insatsu } \\
\text { Sangyô Rengô- } \\
\text { kai }\end{array}$ & $\begin{array}{l}\text { Japan Federation } \\
\text { of Printing In- } \\
\text { dustries (JFPI) }\end{array}$ & $\mathrm{x}$ & & & & & $\mathrm{X}$ & $\mathrm{x}$ & $\mathrm{x}$ & & 32 & 1985 & 66 \\
\hline $\begin{array}{l}\text { 日本羽毛 } \\
\text { 製品協同 } \\
\text { 組合 }\end{array}$ & $\begin{array}{l}\text { Nihon Umô } \\
\text { Seihin Kyôdô } \\
\text { Kumiai }\end{array}$ & N/A & & & & & & & & & & 27 & N/A & 141 \\
\hline $\begin{array}{l}\text { 社団法人 } \\
\text { 日本エア } \\
\text { ゾール協 } \\
\text { 会 }\end{array}$ & $\begin{array}{l}\text { Shadan Hôjin } \\
\text { Nihon Eazôru } \\
\text { Kyôkai }\end{array}$ & $\begin{array}{l}\text { Aerosol Industry } \\
\text { Association of } \\
\text { Japan }\end{array}$ & & & & & & & & & & 35 & 1954 & 51 \\
\hline $\begin{array}{l}\text { 日本衛生 } \\
\text { 設備機器 } \\
\text { 工業会 }\end{array}$ & $\begin{array}{l}\text { Nihon Eisei } \\
\text { Setsubi Kiki } \\
\text { Kôgyôkai }\end{array}$ & N/A & $\mathrm{x}^{*}$ & & $\mathrm{x}$ & & $\mathrm{x}$ & & & & & 36 & 1948 & 7 \\
\hline
\end{tabular}




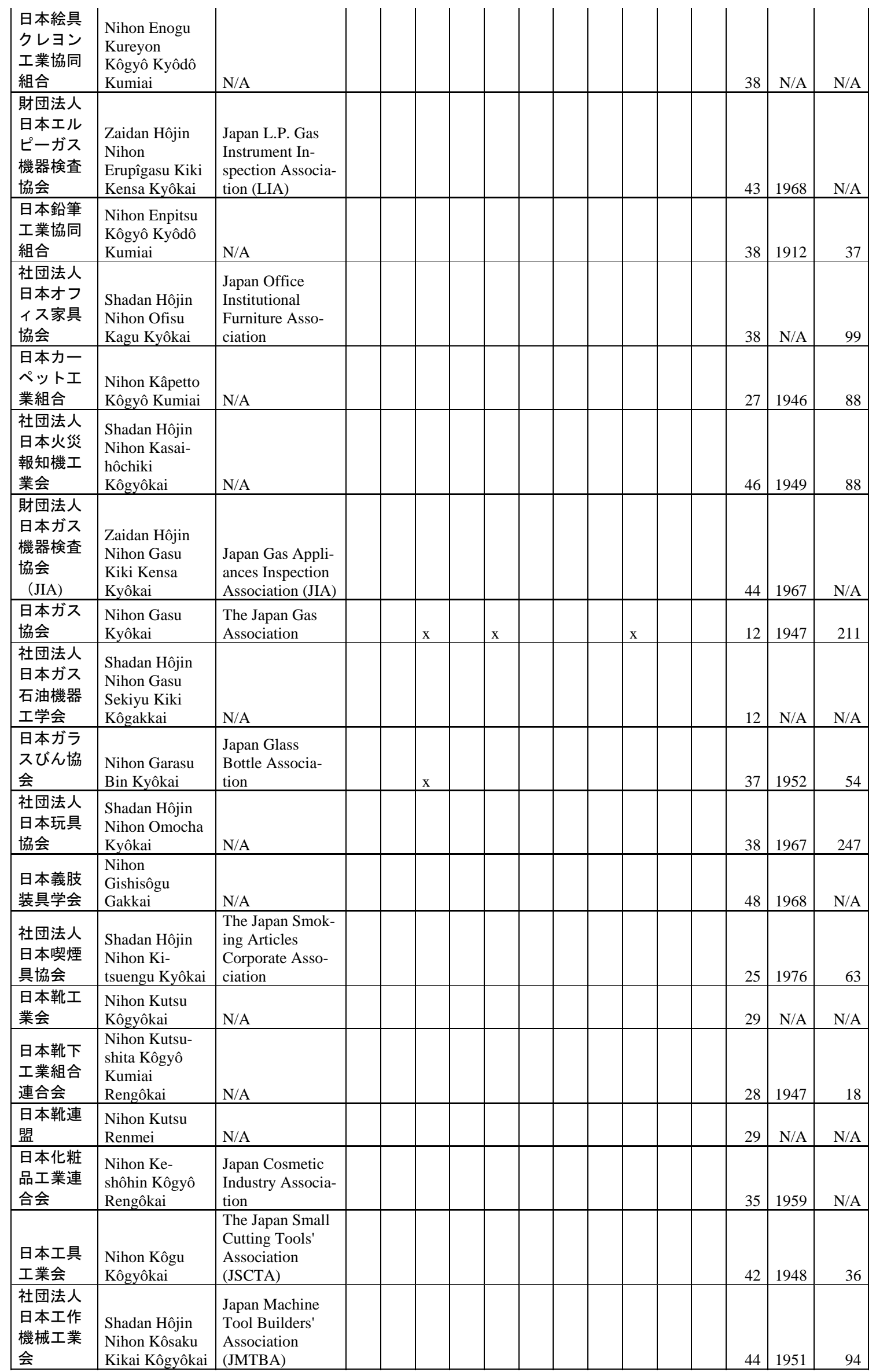




\begin{tabular}{|c|c|c|c|c|c|c|c|c|c|c|c|c|}
\hline $\begin{array}{l}\text { 日本香料 } \\
\text { 工業会 }\end{array}$ & $\begin{array}{l}\text { Nihon Kôryô } \\
\text { Kôgyôkai }\end{array}$ & $\begin{array}{l}\text { Japan Flavor \& } \\
\text { Fragrance Ma- } \\
\text { terials Associa- } \\
\text { tion (JFFMA) }\end{array}$ & & & & & & & & 35 & N/A & 49 \\
\hline $\begin{array}{l}\text { 日本ゴム } \\
\text { 履物協会 }\end{array}$ & $\begin{array}{l}\text { Nihon Gomu } \\
\text { Hakimono } \\
\text { Kyôkai }\end{array}$ & $\begin{array}{l}\text { Japan Rubber } \\
\text { Footwear Manu- } \\
\text { facturers' Asso- } \\
\text { ciation (JRFMA) }\end{array}$ & & & & & & & & 36 & 1956 & 17 \\
\hline $\begin{array}{l}\text { 社団法人 } \\
\text { 日本サッ } \\
\text { シ協会 }\end{array}$ & $\begin{array}{l}\text { Shadan Hôjin } \\
\text { Nihon Sasshi } \\
\text { Kyôkai }\end{array}$ & $\begin{array}{l}\text { Japan Sash } \\
\text { Manufacturers } \\
\text { Association } \\
\text { (JSMA) } \\
\end{array}$ & & & & & & & & 42 & 1947 & 168 \\
\hline $\begin{array}{l}\text { 日本色彩 } \\
\text { 学会 }\end{array}$ & $\begin{array}{l}\text { Nihon Shikisai } \\
\text { Gakkai }\end{array}$ & $\begin{array}{l}\text { The Color Sci- } \\
\text { ence Association } \\
\text { of Japan }\end{array}$ & & & & & & & $\mathrm{x}$ & 35 & N/A & 4 \\
\hline $\begin{array}{l}\text { 日本自動 } \\
\text { 車工業会 }\end{array}$ & $\begin{array}{l}\text { Nihon Jidôsha } \\
\text { Kôgyôkai }\end{array}$ & $\begin{array}{l}\text { Japan Automo- } \\
\text { bile Manufactur- } \\
\text { ers Association } \\
\text { (JAMA) }\end{array}$ & & $\mathrm{x}$ & & $\mathrm{x}$ & & & & 49 & 1967 & 14 \\
\hline $\begin{array}{l}\text { 社団法人 } \\
\text { 日本自動 } \\
\text { 認識シス } \\
\text { テム協会 }\end{array}$ & $\begin{array}{l}\text { Shadan Hôjin } \\
\text { Nihon Jidô } \\
\text { Ninshiki } \\
\text { Shisutemu } \\
\text { Kyôkai } \\
\end{array}$ & $\begin{array}{l}\text { Japan Automatic } \\
\text { Identification } \\
\text { Systems Associa- } \\
\text { tion (JAISA) }\end{array}$ & & & & & & & & 46 & 1986 & 168 \\
\hline $\begin{array}{l}\text { 日本自動 } \\
\text { 販売機工 } \\
\text { 業会 } \\
\end{array}$ & $\begin{array}{l}\text { Nihon Jidôhan- } \\
\text { baiki Kôgyôkai }\end{array}$ & $\begin{array}{l}\text { Japan Vending } \\
\text { Machine Manu- } \\
\text { facturers Asso- } \\
\text { ciation (JVMA) } \\
\end{array}$ & & & & & $\mathrm{x}$ & & & 46 & 1963 & 72 \\
\hline $\begin{array}{l}\text { 社団法人 } \\
\text { 日本住宅 } \\
\text { 協会 }\end{array}$ & $\begin{array}{l}\text { Shadan Hôjin } \\
\text { Nihon Jûtaku } \\
\text { Kyôkai }\end{array}$ & $\begin{array}{l}\text { Japan Housing } \\
\text { Association }\end{array}$ & & $\mathrm{x}$ & & & & $\mathrm{x}^{*}$ & & 52 & 1952 & 688 \\
\hline $\begin{array}{l}\text { 社団法人 } \\
\text { 日本建材 } \\
\text { - 住宅設 } \\
\text { 備産業協 } \\
\text { 会 }\end{array}$ & $\begin{array}{l}\text { Shadan Hôjin } \\
\text { Nihon Kenzai } \\
\text { Jûtaku Setsubi } \\
\text { Sangyô Kyôkai }\end{array}$ & $\begin{array}{l}\text { Japan Construc- } \\
\text { tion Material \& } \\
\text { Housing Equip- } \\
\text { ment Industries } \\
\text { Federation (J- } \\
\text { CHIF) } \\
\end{array}$ & & & $\mathrm{x}$ & & & & $\mathrm{x}$ & 51 & 2005 & 166 \\
\hline $\begin{array}{l}\text { 社団法人 } \\
\text { 日本消火 } \\
\text { 器工業会 }\end{array}$ & $\begin{array}{l}\text { Shadan Hôjin } \\
\text { Nihon Shôkaki } \\
\text { Kôgyôkai }\end{array}$ & $\begin{array}{l}\text { Japan Fire Extin- } \\
\text { guisher Manufac- } \\
\text { turers' Associa- } \\
\text { tion (JFEMA) }\end{array}$ & & & & $\mathrm{x}$ & & & & 35 & 1961 & 16 \\
\hline $\begin{array}{l}\text { 財団法人 } \\
\text { 日本消防 } \\
\text { 設備安全 } \\
\text { センター }\end{array}$ & $\begin{array}{l}\text { Zaidan Hôjin } \\
\text { Nihon Shôbô } \\
\text { Setsubi Anzen } \\
\text { Sentâ }\end{array}$ & $\begin{array}{l}\text { Fire Equipent and } \\
\text { Safety Center of } \\
\text { Japan }\end{array}$ & $\mathrm{x}$ & $\mathrm{x}$ & & $\mathrm{x}$ & $\mathrm{x}$ & & & N/A & 1975 & N/A \\
\hline $\begin{array}{l}\text { 社団法人 } \\
\text { 日本照明 } \\
\text { 器具工業 } \\
\text { 会 }\end{array}$ & $\begin{array}{l}\text { Shadan Hôjin } \\
\text { Nihon } \\
\text { Shômeikigu } \\
\text { Kôgyôkai } \\
\end{array}$ & $\begin{array}{l}\text { Japan Luminaires } \\
\text { Association }\end{array}$ & & & $\mathrm{x}$ & $\mathrm{X}^{*}$ & & & & 46 & 1942 & 89 \\
\hline $\begin{array}{l}\text { 日本石鹸 } \\
\text { 洗剂工業 } \\
\text { 会 }\end{array}$ & $\begin{array}{l}\text { Nihon Sekken } \\
\text { Senzai } \\
\text { Kôgyôkai } \\
\end{array}$ & $\begin{array}{l}\text { Japan Soap and } \\
\text { Detergent Asso- } \\
\text { ciation }\end{array}$ & & & & & & & & 35 & 1950 & 60 \\
\hline $\begin{array}{l}\text { 財団法人 } \\
\text { 日本繊維 } \\
\text { 製品品質 } \\
\text { 技術セン } \\
\text { ター }\end{array}$ & $\begin{array}{l}\text { Shadan Hôjin } \\
\text { Nihon Sen'i } \\
\text { Seihin Hin- } \\
\text { shitsu Gijutsu } \\
\text { Sentâ }\end{array}$ & $\begin{array}{l}\text { Japan Textile } \\
\text { Products Quality } \\
\text { and Technology } \\
\text { Center (QTEC) }\end{array}$ & & $\mathrm{x}$ & & & & & & $26^{*}$ & 1948 & N/A \\
\hline $\begin{array}{l}\text { 財団法人 } \\
\text { 日本船舶 } \\
\text { 標準協会 }\end{array}$ & $\begin{array}{l}\text { Zaidan Hôjin } \\
\text { Nihon Senpaku } \\
\text { Hyôjun Kyôkai }\end{array}$ & N/A & & & & & & & & 49 & 1969 & N/A \\
\hline $\begin{array}{l}\text { 日本大衆 } \\
\text { 薬工業協 } \\
\text { 会 }\end{array}$ & $\begin{array}{l}\text { Nihon Tai- } \\
\text { shûyaku Kôgyô } \\
\text { Kyôkai }\end{array}$ & $\begin{array}{l}\text { Japan Self- } \\
\text { Medication } \\
\text { Industry (JSMI) }\end{array}$ & & & & & & & & 35 & 1971 & 83 \\
\hline $\begin{array}{l}\text { 日本暖房 } \\
\text { 機器工業 } \\
\text { 会 }\end{array}$ & $\begin{array}{l}\text { Nihon Dan- } \\
\text { bôkiki } \\
\text { Kôgyôkai }\end{array}$ & $\begin{array}{l}\text { Japan Heating } \\
\text { Industrial Asso- } \\
\text { ciation }\end{array}$ & & & & & & & & 44 & 1961 & 50 \\
\hline $\begin{array}{l}\text { 社団法人 } \\
\text { 日本通信 } \\
\text { 販売協会 }\end{array}$ & $\begin{array}{l}\text { Shadan Hôjin } \\
\text { Nihon Tsûshin } \\
\text { Hanbai Kyôkai }\end{array}$ & $\begin{array}{l}\text { Japan Direct } \\
\text { Marketing Asso- } \\
\text { ciation (JDMA) }\end{array}$ & & & & $\mathrm{x}$ & & & & 86 & 1983 & 745 \\
\hline
\end{tabular}




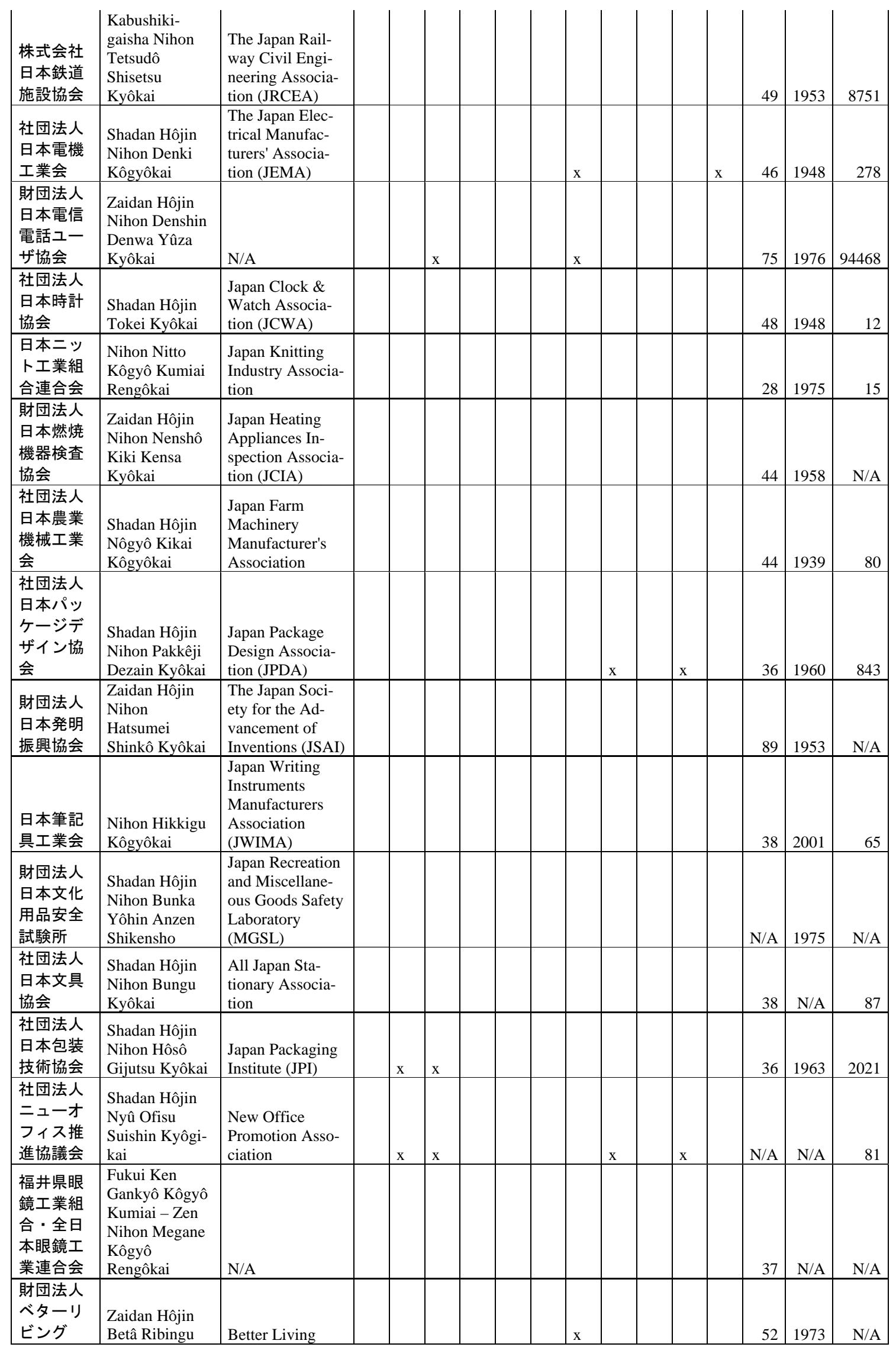




\begin{tabular}{|c|c|c|c|c|c|c|c|c|c|c|c|c|c|}
\hline $\begin{array}{l}\text { 社団法人 } \\
\text { レジャー } \\
\text { ・スポー } \\
\text { ツダイビ } \\
\text { ング産業 } \\
\text { 協会 }\end{array}$ & $\begin{array}{l}\text { Shadan Hôjin } \\
\text { Rejâ Supôtsu } \\
\text { Daibingu } \\
\text { Sangyô Kyôkai }\end{array}$ & $\begin{array}{l}\text { Japan Recrea- } \\
\text { tional Diving } \\
\text { Industry Associa- } \\
\text { tion (JRDA) }\end{array}$ & & & & & & & & & N/A & N/A & 74 \\
\hline $\begin{array}{l}\text { 社団法人 } \\
\text { 労働科学 } \\
\text { 研究所 }\end{array}$ & $\begin{array}{l}\text { Shadan Hôjin } \\
\text { Rôdô Kagaku } \\
\text { Kenkyûsho }\end{array}$ & $\begin{array}{l}\text { Institute for } \\
\text { Science of La- } \\
\text { bour }\end{array}$ & & $\mathrm{x}$ & & & & & & & N/A & 1921 & N/A \\
\hline $\begin{array}{l}\text { 日本工業 } \\
\text { 標準調査 } \\
\text { 会（J I } \\
\text { S C ) }\end{array}$ & $\begin{array}{l}\text { Nihon Kôgyô } \\
\text { Hyôjun Chôsa- } \\
\text { kai }\end{array}$ & $\begin{array}{l}\text { Japanese In- } \\
\text { dustrial Standards } \\
\text { Committee }\end{array}$ & $\mathrm{x}$ & $\mathrm{x}$ & $\mathrm{x}$ & & & & & & N/A & N/A & N/A \\
\hline $\begin{array}{l}\text { (財)日本 } \\
\text { 規格協会 }\end{array}$ & $\begin{array}{l}\text { (Zai) Nihon } \\
\text { Kikaku Kyôkai }\end{array}$ & $\begin{array}{l}\text { Japanese Stand- } \\
\text { ards Association }\end{array}$ & $\mathrm{X}$ & $\mathrm{x}$ & & & & & & & N/A & 1945 & N/A \\
\hline $\begin{array}{l}\text { 産業技術 } \\
\text { 総合研究 } \\
\text { 所 }\end{array}$ & $\begin{array}{l}\text { Sangyô Gijutsu } \\
\text { Sôgô Ken- } \\
\text { kyûsho }\end{array}$ & $\begin{array}{l}\text { National Institute } \\
\text { of Advanced } \\
\text { Industrial Science } \\
\text { and Technology } \\
\text { (AIST) }\end{array}$ & $\mathrm{x}$ & & & $\mathrm{X}$ & $\mathrm{x}$ & & & & N/A & 2001 & N/A \\
\hline $\begin{array}{l}\text { 製品評価 } \\
\text { 技術基盤 } \\
\text { 機構 }\end{array}$ & $\begin{array}{l}\text { Seihin Hyôka } \\
\text { Gijutsu Kiban } \\
\text { Kikô }\end{array}$ & $\begin{array}{l}\text { National Institute } \\
\text { of Technology } \\
\text { and Evaluation } \\
\text { (NITE) }\end{array}$ & & $\mathrm{x}$ & & & & & & & N/A & 2001 & N/A \\
\hline $\begin{array}{l}\text { (社) 人間 } \\
\text { 生活工学 } \\
\text { 研究セン } \\
\text { ター（H } \\
\text { QL) }\end{array}$ & $\begin{array}{l}\text { (Zai) Ningen } \\
\text { Seikatsu Kôga- } \\
\text { ku Kenkyû } \\
\text { Sentâ }\end{array}$ & $\begin{array}{l}\text { Research Institute } \\
\text { of Human Engi- } \\
\text { neering for } \\
\text { Quality Life } \\
\text { (HQL) }\end{array}$ & & $\mathrm{x}$ & & & & $\mathrm{x}$ & & & N/A & 1991 & 72 \\
\hline $\begin{array}{l}\text { (財)共用 } \\
\text { 品推進機 } \\
\text { 構 } \\
\end{array}$ & $\begin{array}{l}\text { (Zai) Kyôyôhin } \\
\text { Suishin Kikô }\end{array}$ & $\begin{array}{l}\text { The Accessible } \\
\text { Design Founda- } \\
\text { tion of Japan }\end{array}$ & & $\mathrm{x}$ & & & $\mathrm{x}$ & & & & N/A & 1999 & 57 \\
\hline $\begin{array}{l}\text { 交通エコ } \\
\text { ロジー・ } \\
\text { モビリテ } \\
\text { イ財団 }\end{array}$ & $\begin{array}{l}\text { Kôtsû Ekorojî - } \\
\text { Mobiritî Zaidan }\end{array}$ & $\begin{array}{l}\text { Foundation for } \\
\text { Promoting Per- } \\
\text { sonal Mobility } \\
\text { and Ecological } \\
\text { Transportation } \\
\end{array}$ & & & $\mathrm{x}$ & $\mathrm{x}$ & & & & & 71 & 1994 & 57 \\
\hline $\begin{array}{l}\text { (財)高齢 } \\
\text { 者住宅財 } \\
\text { 団 }\end{array}$ & $\begin{array}{l}\text { (Zai) Kôreisha } \\
\text { Jûtaku Zaidan }\end{array}$ & $\begin{array}{l}\text { Foundation for } \\
\text { Senior Citizen's } \\
\text { Housing }\end{array}$ & & $\mathrm{x}$ & & & & $\mathrm{x}$ & & & 52 & 1993 & 131 \\
\hline $\begin{array}{l}\text { 貿易振興 } \\
\text { 会（JE } \\
\text { TRO） }\end{array}$ & $\begin{array}{l}\text { Bôeki } \\
\text { Shinkôkai }\end{array}$ & $\begin{array}{l}\text { Japan External } \\
\text { Trade Organiza- } \\
\text { tion }\end{array}$ & & & & & & & & & N/A & 1958 & N/A \\
\hline $\begin{array}{l}\text { 日本人間 } \\
\text { 工学会 }\end{array}$ & $\begin{array}{l}\text { Nihon Ningen } \\
\text { Kôgakkai }\end{array}$ & $\begin{array}{l}\text { Japan Ergonom- } \\
\text { ics Society }\end{array}$ & & $\mathrm{x}$ & & & $\mathrm{x}$ & $\mathrm{X}$ & & & N/A & 1964 & N/A \\
\hline $\begin{array}{l}\text { 日本师ビリ } \\
\text { T-ションエ学 } \\
\text { 協会 } \\
\end{array}$ & $\begin{array}{l}\text { Nihon Ri- } \\
\text { habiritêshon } \\
\text { Kôgaku Kyôkai }\end{array}$ & $\begin{array}{l}\text { Rehabilitation } \\
\text { Engineering } \\
\text { Society of Japan } \\
\text { (RESJA) }\end{array}$ & & & $\mathrm{X}$ & & $\mathrm{x}$ & & & $\mathrm{X}$ & N/A & 1986 & N/A \\
\hline $\begin{array}{l}\text { 日本生活 } \\
\text { 支援工学 } \\
\text { 会 }\end{array}$ & $\begin{array}{l}\text { Nihon Seikatsu } \\
\text { Shien Kôgakkai }\end{array}$ & $\begin{array}{l}\text { Japanese Society } \\
\text { for Wellbeing } \\
\text { Science and } \\
\text { Assistive Tech- } \\
\text { nology }\end{array}$ & & $\mathrm{x}$ & & & & & $\mathrm{x}$ & & N/A & N/A & 69 \\
\hline
\end{tabular}

Annotation: Internet research on the associations' homepages in Japanese by mainly using the keywords "universal design", "barrierfree", "accessible design", "silver business", and "silver market". Most entries were found with the keyword "universal design"; the other terms are, by the associations themselves, obviously too much associated with the gerontological market.

Total amount of activities: 106, average number of activities among the 49 active associations etc.: 2.16 Associations founded 44 years before (on average)

*1) Includes active production and/or presentation of merchandise.

*2) Includes participation and/or invitations and/or information about symposium.

" $\mathrm{x} *$ Indicates any further activity.

$*$ The classification of this association to the industrial standard classification is not clear cut, but this classification is the most closest one. 
Appendix 2: Classification of industries and Trade Associations active in the respective industries

- $\quad \underline{0}$ - Agriculture, forestry and fishery products $(0 \%)$

- $\quad 01$ - Products of agriculture, horticulture and market gardening

- $\quad 02$ - Live animals and animal products

- $\quad \underline{03}$ - Forestry and logging products

- $\quad 04$ - Fish and other fishing products

- $\quad 1$ - Ores and minerals; electricity, gas and water (1.69\%)

- $\quad 11$ - Coal and lignite; peat

- $\quad 12$ - Crude petroleum and natural gas (2)

- $\quad \underline{13}$ - Uranium and thorium ores

- $\quad 14$ - Metal ores

- $\quad 15$ - Stone, sand and clay

- 16 - Other minerals

- $\quad \overline{17}$ - Electricity, town gas, steam and hot water

- 18 - Water

- $\quad \underline{2}$ - Food products, beverages and tobacco; textiles, apparel and leather products $(9.32 \%)$

- 21 - Meat, fish, fruit, vegetables, oils and fats

- 22 - Dairy products

- 23 - Grain mill products, starches and starch products; other food products

- 24 - Beverages

- 25 - Tobacco products (1)

- $\quad 26$ - Yarn and thread; woven and tufted textile fabrics (1)

- $\quad 27$ - Textile articles other than apparel (2)

- $\quad 28$ - Knitted or crocheted fabrics; wearing apparel (3)

- $\quad 29$ - Leather and leather products; footwear (4)

- $\quad 3$ - Other transportable goods, except metal products, machinery and equipment $(27.12 \%)$

- 31 - Products of wood, cork, straw and plaiting materials

- $\quad 32$ - Pulp, paper and paper products; printed matter and related articles (5)

- $\quad 33$ - Coke oven products; refined petroleum products; nuclear fuel

- 34 - Basic chemicals (1)

- $\quad \underline{35}$ - Other chemical products; man-made fibres (9)

- $\quad 36$ - Rubber and plastics products (5)

- $\quad \underline{37}$ - Glass and glass products and other non-metallic products n.e.c. (2)

- $\quad \underline{38}$ - Furniture; other transportable goods n.e.c. (10)

- $\quad 39$ - Wastes or scraps

- $\quad 4$ - Metal products, machinery and equipment (30.51\%)

- 41 - Basic metals

- $\quad \underline{42}$ - Fabricated metal products, except machinery and equipment (5)

- $\quad 43$ - General purpose machinery (1)

- 44 - Special purpose machinery (8)

- $\quad \underline{45}$ - Office, accounting and computing machinery

- $\quad \underline{46}$ - Electrical machinery and apparatus (8)

- $\quad 47$ - Radio, television and communication equipment and apparatus (2)

- $\quad 48$ - Medical appliances, precision and optical instruments, watches and clocks (6)

- $\quad \underline{49}$ - Transport equipment (6)

- $\quad 5$ - Construction work and constructions; land (4.24\%)

- $\quad \underline{51}$ - Construction work (1)

- $\quad \underline{52}$ - Constructions (4)

- $\quad \underline{53}$ - Land

- $\quad \underline{6}$ - Trade services; hotel and restaurant services $(0.85 \%)$

- $\quad 61$ - Sale, maintenance and repair services of motor vehicles and motorcycles

- $\quad \underline{62}$ - Commission agents' and wholesale trade services, except of motor vehicles and motorcycles (1)

- $\quad 63$ - Retail trade services; repair services of personal and household goods

- 64 - Hotel and restaurant services

- $\quad$ - Transport, storage and communications services $(2.54 \%)$

- 71 - Land transport services (1)

- $\quad \underline{72}$ - Water transport services 
- $\quad \underline{73}$ - Air transport services

- $\overline{74}$ - Supporting and auxiliary transport services

- $\quad \underline{75}$ - Post and telecommunications services (2)

- $\quad \underline{8}$ - Business services; agricultural, mining and manufacturing services $(6.78 \%)$

- $\quad 81$ - Financial intermediation services and auxiliary services therefore

- $\quad \underline{82}$ - Real estate services

- $\quad 83$ - Leasing or rental services without operator

- 84 - Computer and related services (1)

- 85 - Research and development services

- $\quad \underline{86}$ - Legal, accounting, auditing and book-keeping services; taxation services; market research and public opinion polling services; management and consulting services; architectural, engineering and other technical services (4)

- $\quad 87$ - Business services n.e.c. (2)

- $\quad \underline{88}$ - Agricultural, mining and manufacturing services

- $\quad \underline{89}$ - Intangible assets (1)

- $\quad 9$ - Community, social and personal services $(0 \%)$

- 91 - Public administration and other services to the community as a whole; compulsory social security services

- 92 - Education services

- 93 - Health and social services

- 94 - Sewage and refuse disposal, sanitation and other environmental protection services

- 95 - Services of membership organizations

- $\quad \overline{96}$ - Recreational, cultural and sporting services

- 97 - Other services

- 98 - Private households with employed persons

- 99 - Services provided by extraterritorial organizations and bodies

Remark: N/A (20) $(16.95 \%)$ 


\section{Previously published in the Frankfurt Working Papers on East Asia Series}

No. 1 / 2009 Holger Warnk

Searching for Seeds to Rest in Libraries: European Collecting Habits towards Malay Books and Manuscripts in the Nineteenth Century

No. 2 / 2009 Cornelia Storz

The emergence of new industries between path dependency and path plasticity: The case of Japan's software and biotechnology industry

No. 3 / 2011 Susanne Rühle

A different Capitalism? Guanxi-Capitalism and the Importance of Family in Modern China 